\title{
Recent Advances in Emission, Analysis and Remediation technique of Carcinogenic Polycyclic Aromatic Hydrocarbons: A Review
}

\section{NC Kothiyal ${ }^{a}$, Abhay ${ }^{a}$, Laiba Khan ${ }^{a}$ Vaneet Kumar $^{\text {b,* }}$ Saruchic $^{c}$ and Sangram Singh ${ }^{d}$}

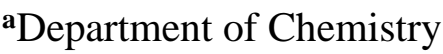

Dr B R Ambedkar National Institute of Technology, Jalandhar- 144011 Punjab (India)

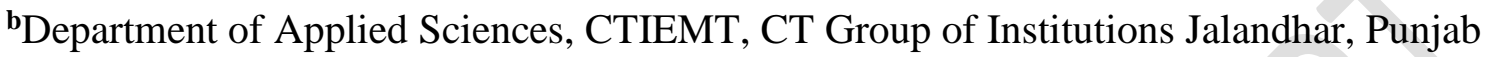
India

'Department of Biotechnology, CTIPS, CT Group of Institutions Jalandhar, Punjab India

dDepartment of Management Studies, CTIEMT, CT Group of Institutions Jalandhar, Punjab India

*Corresponding author: vaneet2106@gmail.com

\section{GRAPHICAL ABSTRACT}

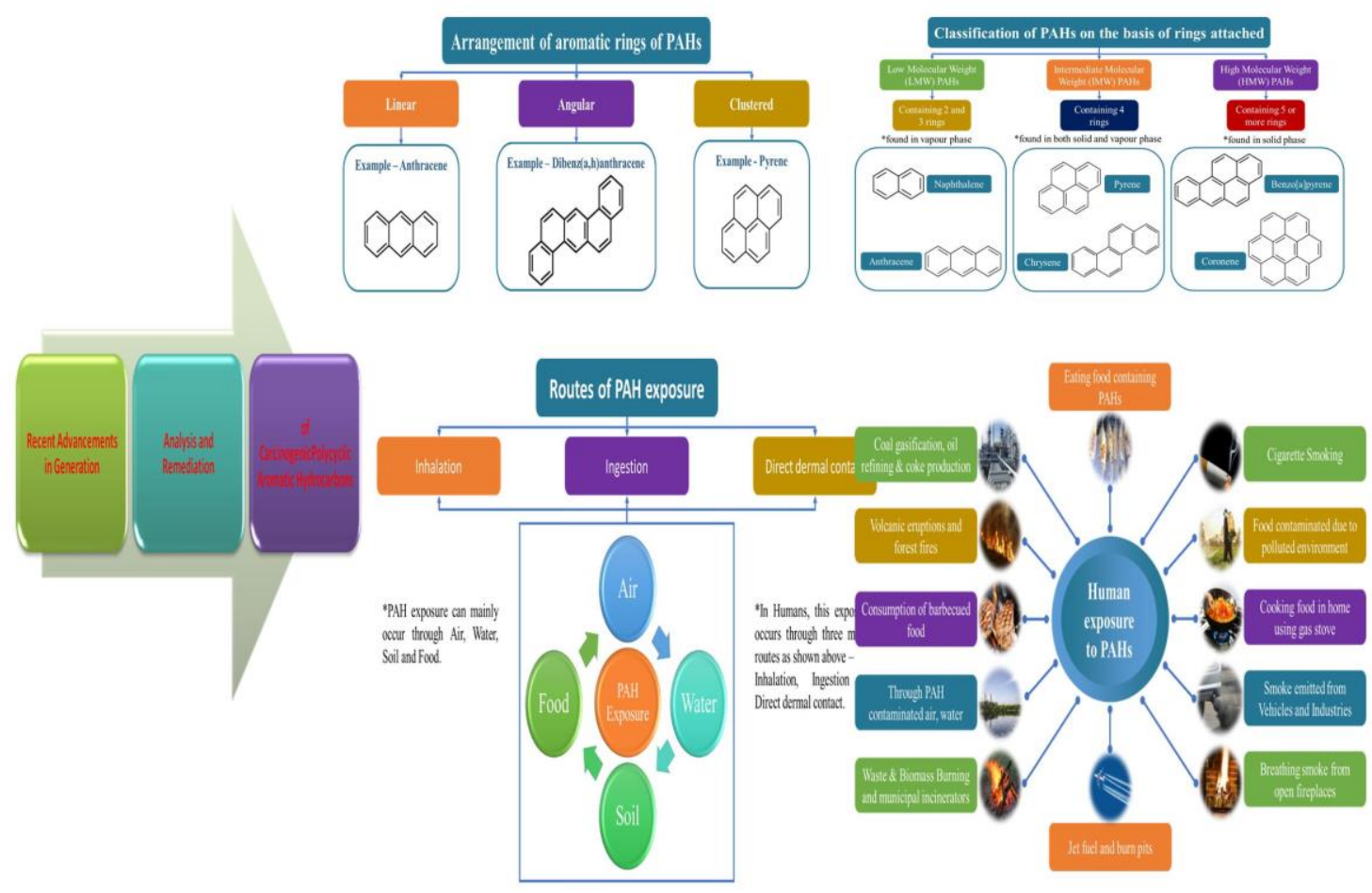

\section{Abstract}

Polycyclic Aromatic Hydrocarbons (PAHs) are aromatic hydrocarbons with three or more fused benzene rings that include carbon and hydrogen. These are thought to be harmful to 
human health, and we cannot avoid being exposed to them because they are widely disseminated throughout the environment. PAHs enter our bodies through the air, water, food, and soil. The developments in different sources of generation, analysis, and remediation approaches are reviewed in this paper based on recent available literature. The chemistry of PAHs, their exposure routes, and their health implications are also discussed. In this manuscript future scope of work as well as removal and reduction of carcinogenic PAHs are also discussed briefly. PAHs are highly carcinogenic in nature for human being. The brief knowledge of PAHs and its latest reduction method for human being are very important.These types of review article are one of the most promising solutions to reduce air pollution issues from environment. This study could be one of the best studies to reduce carcinogenic pollutants from our environment.

Keywords: Polycyclic Aromatic Hydrocarbons (PAHs); sources; chemistry; human exposure; effects; analysis; control of automobile exhaust; degradation

\section{Introduction:}

PAHs correspond to a class of organic pollutants that are omnipresent in our environment. PAHs are present in crude oil; thus they contaminate the environment as the result of oil exploitation, transport and refinement. PAHs also have a source, as the result of the incomplete burning of organic compound, wood, oil, tobacco, and meats cooking at very high temperature. PAHs mostly survive in our environment as gases phase and deposited to airborne $\mathrm{PM}_{2.5}$ (particulate matter). They are generated in our environment as a result of incomplete combustion of fossil fuels and organic materials through different kind of exhaust. A tiny proportion of them primarily exists in the gas phase which may subsequently adsorbed on existing $\mathrm{PM}_{2.5}$ (Kothiyal and Kumar, 2011, 2011a).

PAHs can be generally divided in two groups according to the structure, i.e. structures containing a "bay region" and those without it. Typically, PAHs containing a bay region are considered to be carcinogenic, whereas PAHs without a bay region are comparatively less carcinogenic in nature (Kumar and Kothiyal, 2012). There are more than 1000 PAHs are present in our environment but all of them are not carcinogenic in nature for human being. Out of 1000 PAHs only 16 PAHs are carcinogenic in nature for human being given in figure number 2.

PAHs (Polycyclic Aromatic Hydrocarbons) are types of Polycyclic Organic Matter (POM). Compounds with three or more fused aromatic rings make up the POM. C, H, O, N, and S can all be found in the structures of these molecules. PAHs, on the other hand, are made up entirely of carbon and hydrogen. PAHs with two to seven fused benzene rings (e.g. naphthalene) are most commonly found in the environment, while PAHs with more rings are also present. PAHs associated with particles are thought to be particularly hazardous to human health. (Choi. H., et. al, 2010).

The most common PAH Benzo[a]pyrene $(\mathrm{B}[\mathrm{a}] \mathrm{P})$ which is highly carcinogenic in nature. Actually, they are a widespread collection of many chemically related molecules that are persistent in the environment, having different structures and toxic effects. They can enter the environment in a number of ways, and they are not present as individual molecules but as the mixtures of contaminants. They can interfere with the cellular membranes disturbing their function and also the particular enzymes connected with the membrane and producing toxic effects in our body (M. Naushad, 2014, M. Naushad et al., 2015, 2015a, 2019). That is why 
PAHs have been shown to have carcinogenic (cancer-causing) and mutagenic (changes occur in the DNA of cells) properties.

PAHs are generated from natural (e.g. forest fires, volcanic eruptions) or man-made (automobiles \& industry emission, cigarette smoke) combustion sources. PAHs are widely spread in the environment (whether in air, soil or in water). (Abdel-Shafy, H. I., et al. 2016). That's why PAH exposure is inevitable. We cannot escape from their harmful effects. They are present everywhere around us, from the food that we cook and eat to the smoke (from vehicles and industries) that we inhale while going outside.

\section{Chemistry of PAHs}

PAHs are typically colourless, white, or light-yellow solid compounds made up of two or more fused aromatic rings having carbon and hydrogen in them. Aromatic rings can be arranged in space in a linear, angular, or clustered manner.(Abdel-Shafy, H. I., et al. 2016).

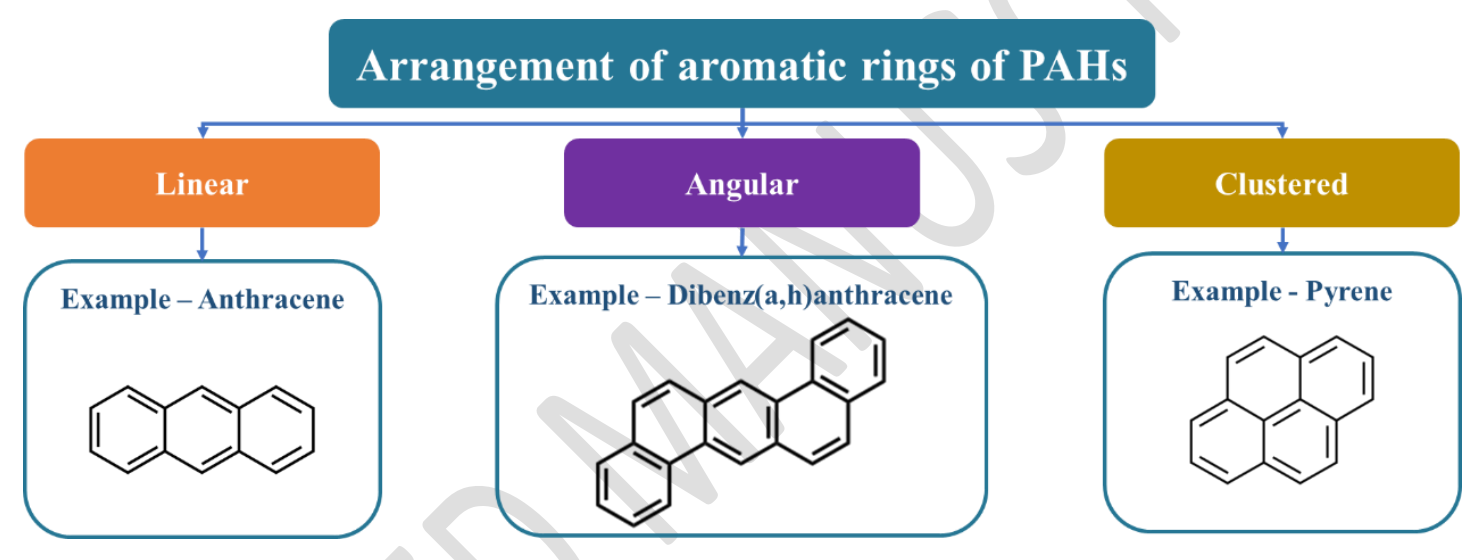

Figure 1. Molecular arrangements of Polycyclic Aromatic Hydrocarbons (PAHs)(AbdelShafy, H. I., et al. 2016).

Based upon these structural arrangements, a variety of PAHs have been identified. The most extensively studied of them are the 16 which are referred to as priority pollutants are shown in figure 2.Now from the structures, it is clear that there is different arrangement as well as number of rings present in these structures. So, depending upon the ring size and arrangement, the PAHs are of Low Molecular Weight (LMW), Intermediate Molecular Weight (IMW) and High Molecular Weight (HMW) types. LMW PAHs contain two/three fused aromatic rings (e.g. Naphthalene, Anthracene) and are primarily exist in the vapour phase in the environment. IMW PAHs are those containing four aromatic rings (e.g. Pyrene, Chrysene) and are divisible into two phases - solid and vapour, based on air temperature. HMWPAHs are those containing five or more aromatic rings (e.g. Benzo[a]pyrene, coronene) and are mostly linked to the particles. (Patel, A. B., et. al, 2020). PAHs can also be categorized into small and large PAHs. Small ones are those which contain six fused aromatic rings while large ones are those which contain above six fused aromatic. It is to be noted that Benzene is not a PAH. Depending on their structures, PAHs are differentiated by their low water solubility, low vapour pressure as well as high melting and boiling temperatures. More the molecular weight of PAH, lower is the water solubility and thus higher is the lipophilicity (lipid loving/soluble), which makes them more resistant. They have low vapour pressure, and very low aqueous solubility (Abdel-Shafy, H. I., et al. 2016). 
<smiles>c1ccc2ccccc2c1</smiles>

Naphthalene<smiles>C1=Cc2cccc3cccc1c23</smiles>

Acenaphthylene<smiles>c1ccc2c(c1)ccc1c3ccccc3ccc21</smiles><smiles>c1ccc2cc3c4ccccc4cc-3ccc2c1</smiles><smiles>c1ccc2cc3ccccc3cc2c1</smiles>

Anthracene<smiles>c1ccc2c(c1)Cc1ccccc1-2</smiles>

Fluorene<smiles>c1cc2ccc3cccc4ccc(c1)c2c34</smiles><smiles>C1=Cc2cc3ccccc3c3cccc4ccc5ccc1c2c5c43</smiles><smiles>c1ccc2c(c1)ccc1ccccc12</smiles>

Phenanthrene<smiles>c1ccc2c(c1)-c1cccc3cccc-2c13</smiles>

Fluoranthene<smiles></smiles>

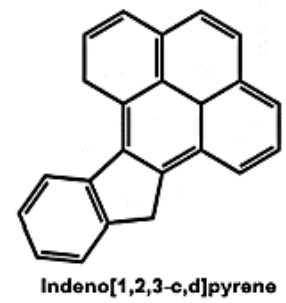<smiles></smiles>

Acenaphthene<smiles>c1ccc2cc3c(ccc4ccccc43)cc2c1</smiles><smiles>c1ccc2c(c1)c1cccc3c4ccccc4c2cc13</smiles><smiles></smiles>

Figure2. Structures of the16 PAHs enlisted as priority pollutants by US EPA(Ghosal, Ghosh et al. 2016)

The properties vapour pressure and aqueous solubility are inversely proportional to the molecular weight, but the resistance to oxidation and reduction is directly proportional to it. PAHs' water solubility drops with each extra ring. PAHs, on the other hand, are highly soluble in organic solvents as they are highly lipophilic in nature. The UV absorbance spectra of different PAHs are different. Even each isomer has a different UV absorbance spectrum because each ring structure absorbs a different wavelength of UV-light. This is very beneficial while studying different PAHs. The majority of PAHs show the phenomenon known as fluorescence. The PAHs are photochemically decomposed when exposed to UV light. Some bacteria in the soil may also potentially breakdown PAHs (Abdel-Shafy, H. I., et al. 2016).

Concluding, different PAHs have different physical and chemical properties such as molecular weight, melting point, boiling point, vapour pressure etc. Based on these different properties, different PAHs are characterized and studied for the research and also they can be categorized on the basis of the harmful effects they produce. It means that not all the PAHs are carcinogenic in nature but only some of them are carcinogenic while other PAHs have different effects on the human body. 


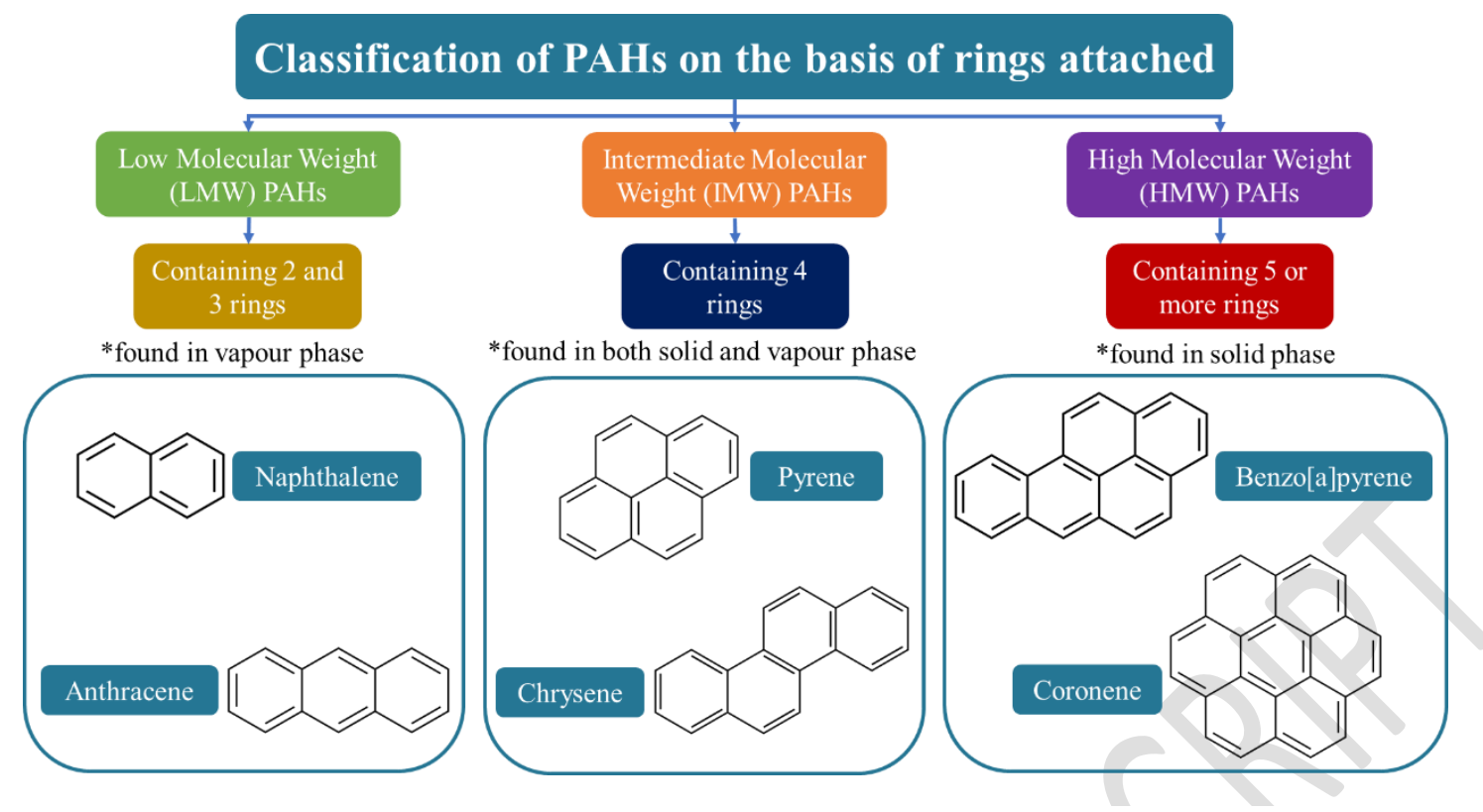

Figure 3. Classification scheme of PAHs based on the rings attached (No. of rings)

\section{Sources of PAHs}

The PAHs are generated by the incomplete combustion of organic matter. There are different activities during which PAHs are generated. For example - cooking, automobile exhaust (which is the major source of PAH generation), industrial exhaust, cigarette smoke, burning biomass, coil smoke, forest fires, volcanic eruptions, oil processing and various polymer manufacturing tasks all are the major sources of PAHgeneration. Various nitro PAHs are also generated by incomplete combustion which are again toxic for the humans as well as animals.

The PAH sources therefore can be anthropogenic (man-made) or natural. (Mojiri, A.,et. al, 2019). Volcanic eruptions, forest fires (not man made), and lightning-caused moorland fires are minor or insignificant sources of natural emissions. The significant predictors of PAH pollution are anthropogenic emission sources, which can be industrial (e.g. coal gasification, polymer manufacturing, pesticides production), mobile (e.g. motor vehicles, trains, aircrafts, ships), household (cooking, using mosquito coils, burning fire in winters, garbage burning and wood burning) or agricultural (spraying pesticides on crops, burning agricultural waste in open).

Domestic and agricultural sources account for the majority of PAH pollution in rural areas, while industrial, mobile, and domestic sources in city areas. PAH concentration also changes with the atmospheric conditions. Its concentration is more in the winter season as compared to other seasons.

PAH sources can also be categorized into pyrogenic, petrogenic, and biogenic depending upon their origin of production as shown in figure 4. (Mojiri, A., et. al, 2019).

Pyrogenic PAHs are generated by burning organic materials unintentionally and incompletely at high temperatures (623-1473 K) in the absence or less amount of oxygen. Pyogenic PAHs are formed by thermal breakdown of complex molecules of petroleum to the lower hydrocarbons. Pyrogenic PAHs are majorly found in the urban areas. Petroleum and its byproducts contain petrogenic PAHs, which are widely distributed due to crude oil storage, transportation, usage, and leakage. HMW PAHs predominate in pyrogenic sources, while 
LMW PAHs predominate in petrogenic sources. Biological entities such as bacteria, phytoplankton, algae, and plants produce biogenic PAHs during the gradual conversion of different molecules biologically.(Mojiri, A., et. al, 2019).

Gaseous PAHs are deposited in the particulate phase in water, soil, and plants via deposition processes (either dry or wet). Because of their low vapour pressure and high hydrophobicity, PAHs which are having three or more fused aromatic rings are highly powerful adsorbents to soil particles. (Abdel-Shafy, H. I., et al. 2016). PAHs accumulate in soil/sediment and thus pollute the groundwater, plants and ultimately the food that we are eating. For example - as the soil gets polluted, the roots of plants absorb PAHs and transport them to other plants and thus enter the food chain. In the current environment, PAH exposure is inescapable.

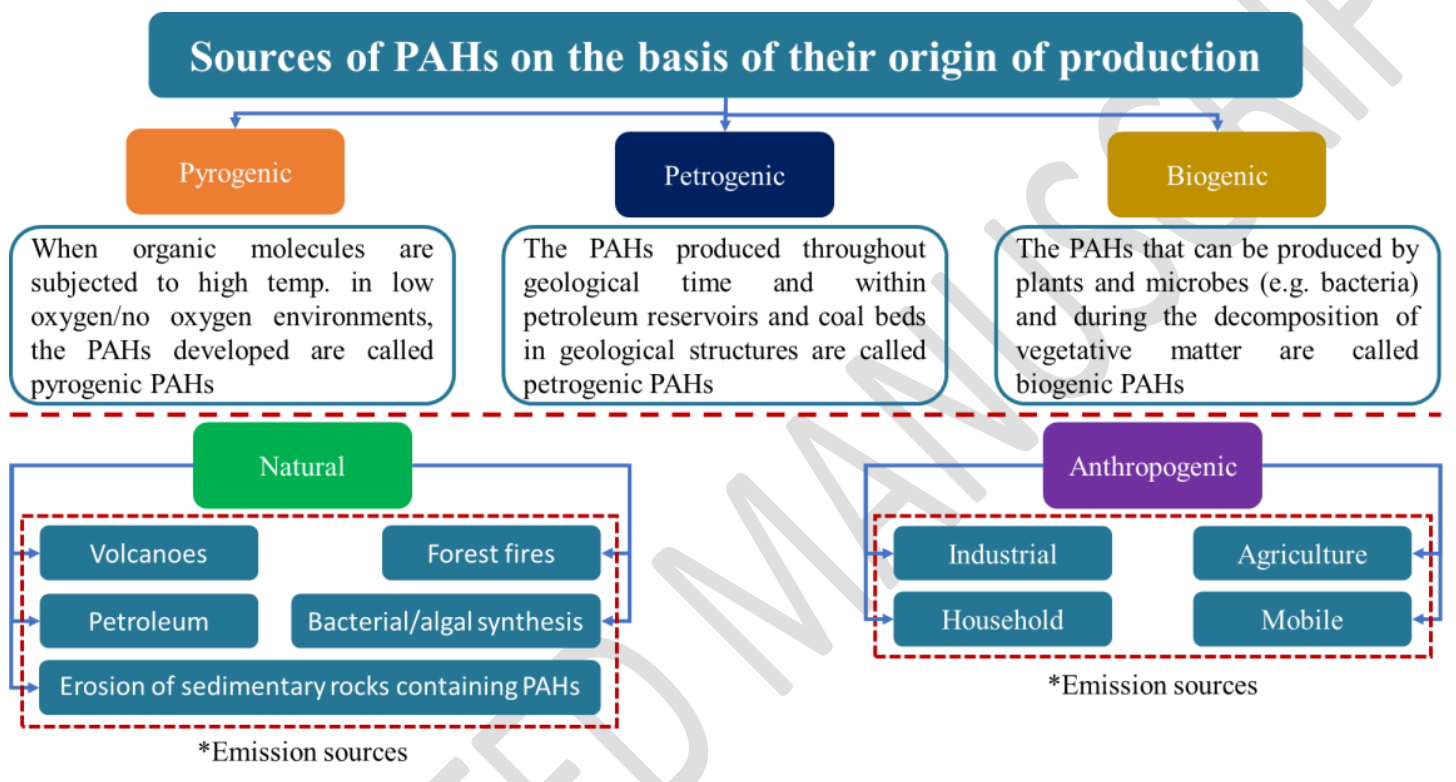

Figure 4. PAHs sources scheme based on their origin of production.

Because the majority of PAH sources are located in the urban areas, their concentration is more in the urban areas than in the rural areas. PAHs are detected in two phases after being discharged into the atmosphere: a vapour phase and a solid phase when adsorb on the particles. PAHs sorb to air particulates more readily than benzene. Individual PAHs are distributed in varying concentrations in the vapour and other physical phases due to the differences in vapour pressures of different PAH molecules (Abdel-Shafy, H. I., et al. 2016).

\section{Routes of PAH exposure and their effects}

The air, water, soil, and food are highly contaminated with carcinogenic PAHs. This contamination can occur either through dermal contact or ingestion or inhalation. It's not necessary that the exposure occurs through one route only. It can occur through more than one route also. 
Now, based on these routes, different people are exposed to PAHs in different ways. Most commonly cigarette smoking, consuming air from open fireplaces, and cooking food containing PAHs are the general routes of their exposure. Mainly PAH exposure occurs through four routes in the environment: Air, food, soil, and water.

\subsection{Air}

As suggested by White, Bradshaw et al. 2016, air sources of PAHs are cooking and smoking and also, according to Verma, Patel et al. 2015, mosquito coils, and PAH-containing materials (e.g., petroleum products, synthetic fuels).

For the majority of the world's population, PAH exposure from solid fuel combustion is a significant public health concern. Individual-level exposures, on the other hand, are still poorly understood. Using stoves in homes and burning fire are major indoor sources of air pollution.

Coming to the outdoor source of air pollution, the primary source is the vehicle exhaust majorly in the urban areas.

\subsection{Food}

PAHs are found widely in the seafood, meats and also in some fruits and vegetables. The way of cooking food also affects the generation of PAHs. Different analysis methods have been developed till date to find out the type of PAHs present in different foods. One such example is of analysing coffee samples by using multiple extraction techniques and by using multiple solvents, for example - hexane, cyclohexane, dichloromethane, acetone etc. Most common PAHs found in daily food are benzo[b]fluoranthene, fluoranthene, and benzo[k]fluoranthene. Also, Chrysene is found in sugar and sweets. (De vos, R. H., et. al, (1990).

\subsection{Soil}

Soil deposition of PAHs is continuously occurring by different mechanism, either dry or wet. Some of these PAHs come from neighbouring sources like automobile emissions from surrounding highways. Other PAHs come from further away and have travelled great distances through the air. As soon as PAHs are deposited in the earth surface, they can become mobile and thus can get transported from one place to another. Now, adsorption process occurs between the soil particles and the PAHs deposited in the soil. The PAHs have the tendency to get adsorbed on the soil particles. So, this adsorption can be used as a parameter for having the information about the mobility of the PAHs.

All surface soils contain carcinogenic PAHs. PAHs, which are carcinogenic, are found in rural soil at concentrations of $10-100 \mathrm{~g} / \mathrm{kg}$, primarily due to atmospheric fallout. These values go above $1000 \mathrm{~g} / \mathrm{kg}$ when it comes to the forest and the agricultural soil. But, in case of the industrial areas, the PAH concentration is even more than agricultural or forest soil because fossil fuel, which is one the major source of PAH emission, it's burning occurs continuously in the industrial sector, which in turn generates PAHs.

The vast majority of urban soil concentrations are between 600 and $3000 \mathrm{~g} / \mathrm{kg}$. As we move to the heavy transportation and industrial region, these values definitely increase. Higher levels are likely to be found near areas of heavy transportation and industrialization. Upper range is considered to be between $1000-3000 \mathrm{~g} / \mathrm{kg}$ (Menzie, C. A., et. al, 1992). 
A simplified solvent extraction and GC/MS/MS methods can be used for the quick determination of PAHs in the soil. The GC/MS/MS can be used to monitor various reactions in a pseudo-multiple mode (PMRM).

\subsection{Water}

PAHs are mostly introduced to surface waterways through different sources including sewage water, industrial effluent, pesticide water runoff, oil leakage in industry. The wet and dry deposition of the particles and vapours in the atmosphere is known as atmospheric fallout. PAHs are thought to be deposited in surface waters by atmospheric deposition. About 80 percent of the PAHs to the oceans in the world are only from air sources. Urban run-off contributes a substantial proportion of PAHs to surface waters carried by sewers. Similarly, in ground water PAHs coming either from industries or agricultural processes or solid waste disposal, it gets contaminated and thus acts as a route of PAH exposure. Also in case of drinking water, higher PAH levels are detected from rainwater collecting basins and water treatment plants. It is to be noted that PAH derivatives (e.g. nitro PAHs, oxygenated PAHs) are more harmful than the parent PAHs. Chlorinated water also one of the sources of PAH exposure. (Manoli, E., et. al, 1999).

In this way, we are exposed to PAHs by coming in contact with surface water, ground water and drinking water containing PAHs (S. Pandey et al., 2020, 2020a, 2021).

\subsection{Effects of PAH exposure}

The PAHs have very significant effect on the human health. Now, these effects can be either short term (e.g. nausea, irritation in eyes, confusion in mind, vomiting) or long term (e.g. asthma, weakened immune system, jaundice, lung abnormalities. Repeated skin contact can cause redness and inflammation. Also, Naphthalene can cause RBC disintegration, when consumed in high amounts.

Reduced immune function, cataracts, kidney and liver damage (e.g. jaundice), breathing issues, asthma-like symptoms, and lung function abnormalities are all possible side effects of chronic (long term) PAH exposure. Mutations, developmental malformations, tumours, and cancer are all caused by biochemical disturbances and cell damage. PAH combinations have been shown to be carcinogenic to humans. Animals also get affected by high amounts of some PAHs causing skin irritation, lung cancer and stomach cancer and it is found out that the chemical carcinogen Benzo[a]pyrene is the first PAH responsible for the cancer in animals. Now other PAHs have also been identified. In the meantime, certain PAH-rich mixes have been recognised as human carcinogens. (Abdel-Shafy, H. I., et al. 2016).

In this way, PAHs are very harmful, toxic as well as carcinogenic to humans.

Based upon the three routes i.e. Inhalation, Ingestion and Direct dermal contact, Humans are exposed to PAHs regularly both on the work and even while sitting at the homes. The routes of PAH exposure are shown in figure 5. So, we can't escape from coming in contact with PAHs. There are a variety of activities, through which we are exposed to PAHs. Some of them are shown in figure 6. 


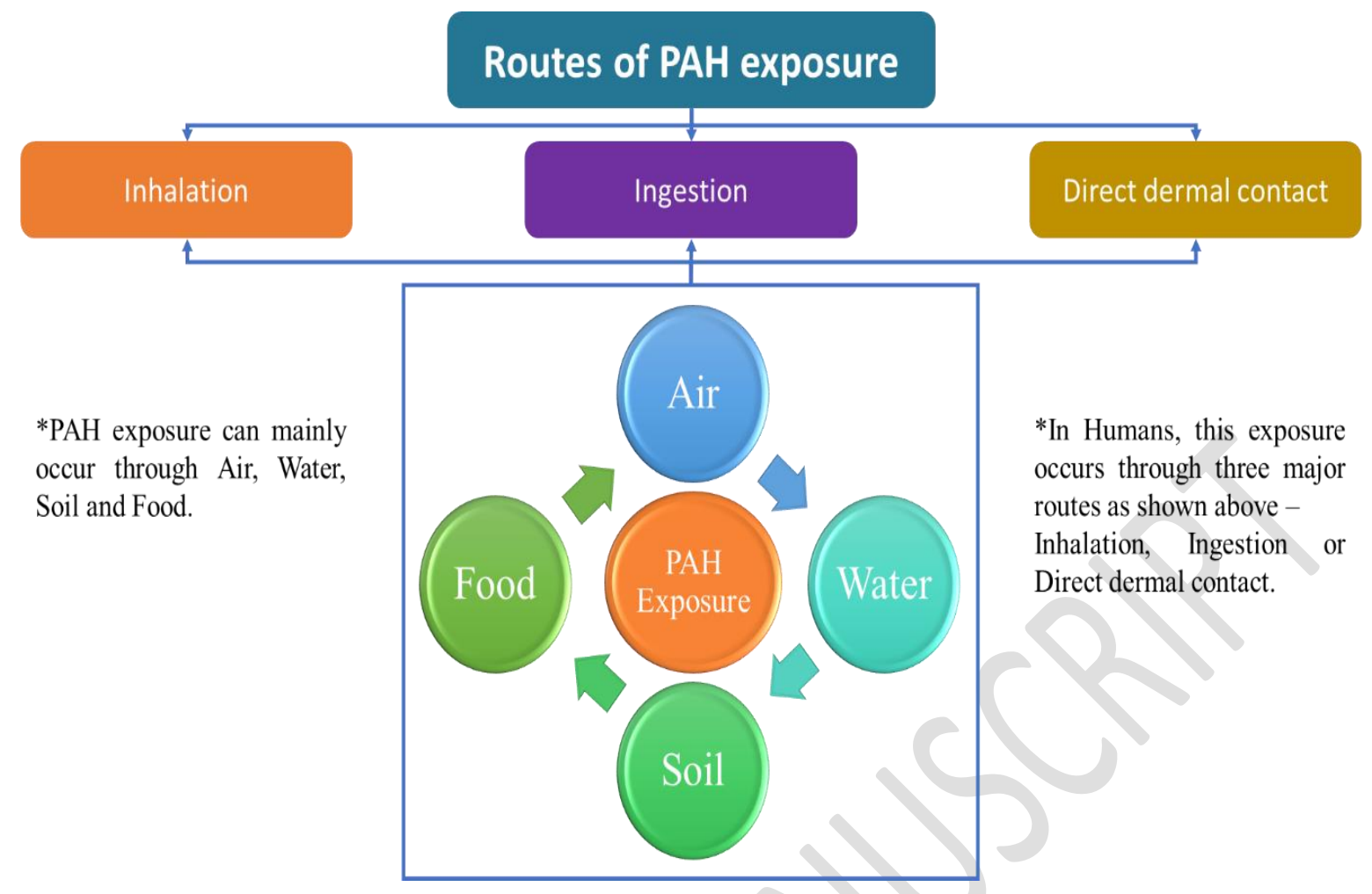

Figure 5. PAH exposure by different kind of routes

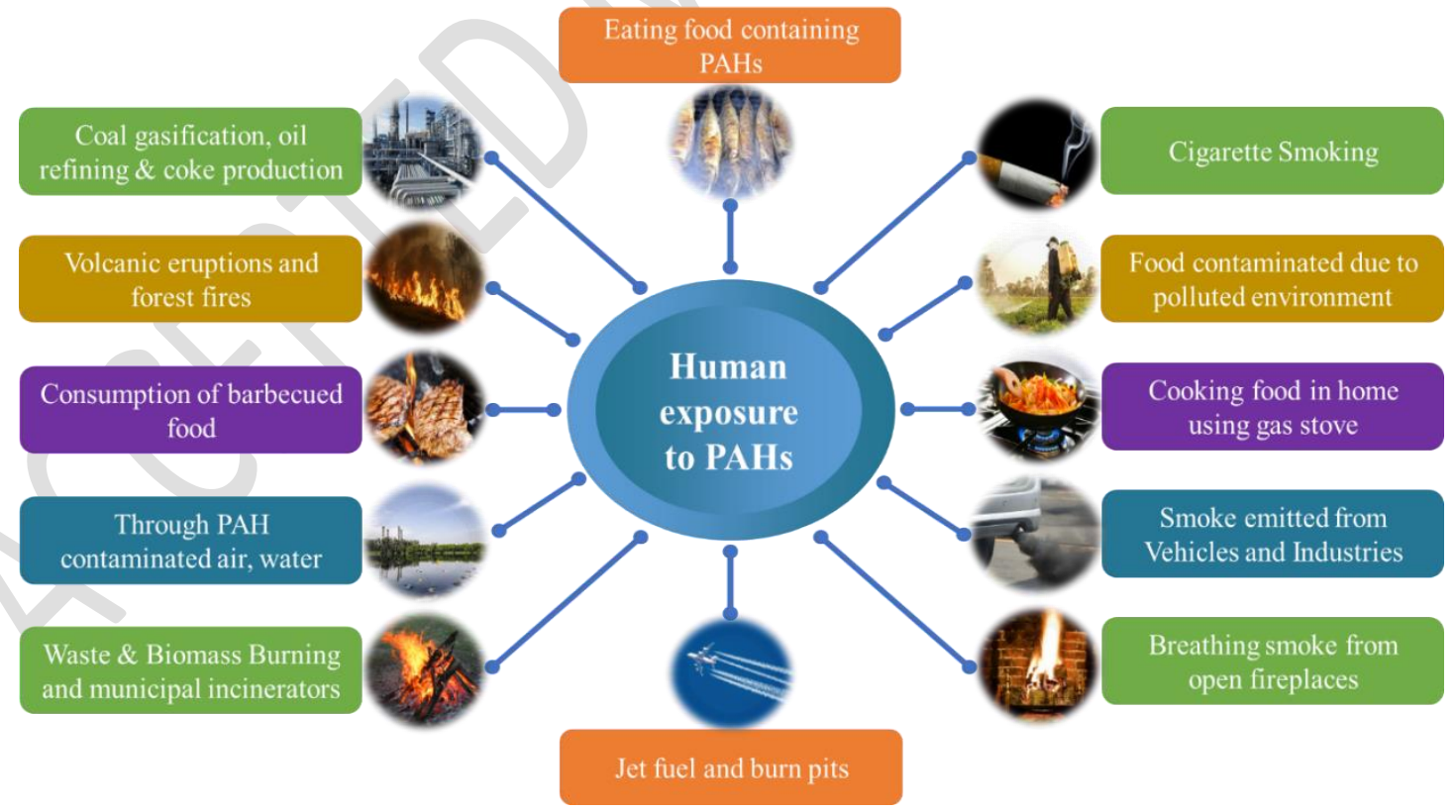

Figure 6: PAH exposure to Human by different kind of routes

\section{Analysis of PAHs:}

Chemical grade used for PAHs analysis was 99.999 (HPLC Grade). A very high purity of chemicals is need on HPLC/GC for PAHs analysis.

\subsection{Sampling:}


To analyse the PAHs in the environment, the very first step is sampling. Now, depending upon the various properties, PAHs exist either in the gas phase or particle phase. These various properties are temperature, pressure, and concentration play an important role in their differentiation in the environment. (Keller, C. D., et. al, 1984). Small PAHs exist in the gas phase and as the size of PAHs increases, existence of PAHs in solid phase increases. Active samplers are used for measuring PAHs in ambient air.

The samplers contain a sampling module that usually has two parts: a filter for collecting the particles and a solid adsorbent for gas-phase contaminants. The other option is passive samplers, which, unlike active samplers, do not require a pump or energy to gather pollutants. Instead, a free movement from air to collecting medium is used. (Tang, N. et. al, 2005).

To summarise, sample equipment selection depends upon the type of the PAHs that are to be analysed and most importantly their compatibility (Kumar et al., 2014).

\subsection{Removal and Clean up:}

The extraction of PAHs from airborne particles is mostly accomplished using solvent-based techniques. The most prevalent methods for removing soluble organic materials are soxhlet and ultrasonic. Different solvent-based methods are available for extraction including microwave extraction and rapid solvent interaction. Solid phase extraction method is now modified for the extraction of PAHs from particles of air, specifically for small PAHs. When compared to the other extraction procedures discussed, the key feature of this method is that it utilises very little solvent. A clean-up process is recommended after liquid extraction to remove various interferences that could compromise $\mathrm{PAH}$ detection in chromatographic analysis (Havenga, W. J., et. al., 2000).

\subsection{Chromatographic Analysis}

Once the sampling, extraction (removal) and cleansing steps are done, then chromatographic techniques are used for the analysis of PAH samples collected. Now, different types of chromatographic techniques are available for the analysis of PAHs, depending upon the type of PAHs (their properties). In different chromatographic methods, sensitive detectors are used. For example - In HPLC systems, the most commonly employed detectors are ultraviolet absorption and fluorescence spectroscopy.

Real time exposure of PAHs cannot be detected by the methods available till now. Actually, this has been the focus of some recent research, which has resulted in the creation of several innovative techniques that are directly relevant to the monitoring of dangerous substances in the workplace. The principles of UV absorption, synchronous luminescence and room temperature phosphorescence are used in most promising analysis methods as shown in table 1. These instruments are extremely sensitive, allowing for the detection of extremely low quantities while also providing information on the PAH content of the sample.

Now, because of the superior selectivity, resolution, and sensitivity, gas chromatography (GC) has traditionally been used to analyse PAHs in environmental samples rather than liquid chromatography (LC). For the chemical investigation of complicated mixtures, GC-MS is one of the most effective analytical techniques available. Mass spectrometry improves gas chromatography's capabilities; the detector is highly specific in nature, giving qualitative as 
well as structural information about the sample. This selectivity of mass spectrometers can ultimately be used for the determination of structure of the sample under investigation. (Chen, P., et., 2015).

The most recent generic method of extraction and analysis of PAHs in animal feed and food samples is developed by. In it, acetonitrile and heptane of HPLC grade were used as the solvents. The Water acetonitrile heptane solid phase extraction (WAHSPE) method was used for the extraction of PAHs from the samples. The instruments used for analysis were GC-MS and LC-MS.

This WAHSPE method has its great advantages in the field of food science as multiple compounds can be investigated by the single sample and definitely if one sample is required, then the efforts required are less and the information gathered about the sample is more. (Eyring, P. et. al, 2021).

Table 1. Common analytical methods used in analysis of PAHs. (Lawal, A. T. 2017)

\begin{tabular}{|c|c|c|c|}
\hline $\mathbf{S} / \mathbf{N}$ & Analytical methods & Target PAHs & Reference \\
\hline 1 & Synchronious fluorecence spectrophtometry & Water & $\begin{array}{l}\text { (Baudot,Viriotetal.1992, Vo- } \\
\text { Dinh,Fetzeretal.1998) }\end{array}$ \\
\hline 2 & Fluorimetry & Food and environmental sample & $\begin{array}{l}\text { (Zhang,Yuanetal.1998,Wenzl, Simon et } \\
\text { al.,2006) }\end{array}$ \\
\hline 3 & IR & Forensic samples & $\begin{array}{l}\text { (Douglas, Emsbo-Mattingly et al. 2015, } \\
\text { Tommasini, Lucotti et al. 2016) }\end{array}$ \\
\hline 4 & HPLC-fluorescence & Indoor samples & (Liaud, Millet et al. 2015) \\
\hline 5 & $\begin{array}{l}\text { Gas chromatography-mass } \\
\text { spectrometry }\end{array}$ & Roasted coffee & $\begin{array}{l}\text { (Guatemala-Morales, Beltrán- Medina et } \\
\text { al. 2016) }\end{array}$ \\
\hline 6 & GC-MS/MS & Petrochemical soil & $\begin{array}{l}\text { (Shang,Kimetal.2014,Zhao, Zhang et al. } \\
\text { 2015, Shimada, Takenakaetal.2016) }\end{array}$ \\
\hline 7 & HPLC and MS & Slurge & (Viguri, Verde et al. 2002) \\
\hline 8 & Fluorescence spectroscopy & Waste slurge & (Aemig, Chéron et al., 2016) \\
\hline 9 & HPLC-fluorescence & Fire events & (Denis, Toney et al. 2012) \\
\hline 10 & LDM (localization-delocalization matrix) & Water & (Sumar, Cook et al. 2015) \\
\hline 11 & FT-IR & Soil & (Swaathy, Kavttha et al. 2014) \\
\hline 12 & $\begin{array}{l}\text { Gaschromatography-triple quadrupole } \\
\text { mass spectrometry }\end{array}$ & Fruit and vegetable & (Banerjee et al., 2012) \\
\hline 13 & Near-infrared (NIR) & Air & (Doney, Candian et al. 2016) \\
\hline 14 & GC/MS & Sediment & $\begin{array}{l}\text { (Retnam,Zakariaetal.2013,Sanil } \\
\text { Kumar,Nairetal.2016) }\end{array}$ \\
\hline 15 & HPLC-fluorescence & Indoor air & (Liaud, Millet et al. 2015) \\
\hline 16 & $\begin{array}{l}\text { Miniaturized membrane inlet mass } \\
\text { spectrometer (mini-MIMS) }\end{array}$ & Sand and Soil & (Frandsen, Janfelt et al. 2008) \\
\hline 17 & $\begin{array}{l}\text { Two-dimensional fluorescence correlation } \\
\text { spectroscopy }\end{array}$ & Water & (Zhou, Zhao et al. 2016) \\
\hline 18 & Polythiophene sensors & Air & (Tiu, Krupadam et al. 2016) \\
\hline 19 & LC-MS/MS & Waste & (Pitarch, Cervera et al. 2016) \\
\hline 20 & $\begin{array}{l}\text { HPLC with fluorescence and } \\
\text { chemiluminescence detections, }\end{array}$ & Air & (Hayakawa 2016) \\
\hline 21 & UHPLC-MS/MS & Biological sample & (Han, Sapozhnikova et al. 2016) \\
\hline 22 & Graphene nanosensor & Aqeuos solution & (Church, Wang et al. 2016) \\
\hline
\end{tabular}




\section{PAHs Emission from Automobile Exhaust}

In urban areas, the automobile exhaust causes the problem of air pollution. The two main types of pollutants, which is emitted from mobile sources are categorized into two parts. The first is regulated and second is unregulated by law. Carbon monoxide (CO), nitrogen oxides $\left(\mathrm{NO}_{\mathrm{x}}\right)$ and unburned hydrocarbons (HC) are considered as regulated pollutants (Westerholm et al.,1988). The exhaust which is not specified by law is the exhaust of unregulated pollutants. The polycyclic aromatic hydrocarbons which are the result of incomplete combustion of fossil fuels are the class of the compound who come under the category of unregulated pollutants (Westerholm et al.,1988). Several authors also tried to investigate the air pollution influence on the people suffering from cancer (Nielsen.,1996). The exhaust emission has different types of unregulated pollutants which are originated from the components present in the fuel (Westerholm et al.,1988). The combustion of gas stoves, diesel, petrol and gasoline all add up to the air pollution containing PAH in addition to the Polycyclic organic matter (POM) (Nielsen.,1996). Due to their carcinogenic nature around 1$10 \%$ person became a sufferer of the lung cancer due to air pollution (Doll and Peto, 1981; Speizer,1986), but it is also a disregarded fact that the content of (POM) with ambient air pollution in year, 1950's and 1960's has a high content of unsubstituted PAH in comparison to air pollution in 1990's and 1980's (Holmberg and Ahlborg, 1983). This is due to the development of effective combustion approach which has led the conversion of PAH into oxygenated PAH and secondly due to the atmospheric transformation of reactive PAH, which is caused by growing of air pollution with $\mathrm{NO}_{\mathrm{x}}$ and ozone (Nielsen.,1983).

A large percent of the population, i.e. around 50\% spend their life within 100 miles of seashore (Hinrichsen.,1997) and pollutants which mainly released from human activities affects the lives of the creature who lives in coastal regions. The water birds like ducks, geese and swans and $70 \%$ of recreational and commercial fishes who spent almost a segment there of the life cycle are largely affected (Dickhut et al.,2000).

Several researchers have investigated the PAH content in densely populated areas and found out that the greatest source of PAH is automobile exhaust (Nielsen., 1996). The traffic contribution is determined in the street of city named Copenhagen and it is investigated that air pollution is at highest in the winter season (Nielsen.,1996). There is also the difference in the concentration of different compounds in the street or in the city area. The BeP is applied as the $\mathrm{PAH}$ indicator and the traffic contribution is determined in the street as well as the city area (Nielsen.,1996).

\subsection{Diesel as a source of PAHs}

The diesel is considered as a heavy fuel which is used for various types of vehicles. They are having the better results and the longevity as compared to gasoline engines (The EPA, 2002). Although, due to some old technology, the emission of hazardous pollutants causes several carcinogenic and mutagenic diseases, but using some advanced technology, the harmful contaminants releasing from the diesel engine reduced up to some extent under government policy to overcome hazardous pollutants. However, the emission control technology can be applied to some old engines which largely reduce toxic pollutants. Therefore, it is concluded 
that the effect of level of (PAHs) and (NPAHs) i.e. Nitrated polycyclic aromatic hydrocarbons due to increase in urbanization is largely due to incomplete combustion of the diesel engine (The EPA, 2002).

The composition mainly consists of several types of gaseous mixture. They also contain some elements including carbon, a little amount of sulphate, nitrate, metals and gases like, CO including some trace elements (Schauer et al, 1999). The PAH and NPAH are the main classes that are generally considered important. NPAH are basically the compounds which result from the nitration of PAH due to incomplete combustion of fuel. NPAH are toxic compounds having mutagenic property (can alter the DNA of cell).

"In countries like Japan" testing shows that more than 99\%, the source of 1-NP generates from exhaustion of diesel. Therefore, the study shows that being the chief source of diesel engine as NPAH, the emission from diesel is considered a major source for PAH (Kumar et al., 2014, Kothiyal et al. 2021).

\subsection{Gasoline as a source of PAHs}

Emissions of PAHs are from several combustion sources which also involves internal combustion engines. The PAH like benzo $(\alpha)$ pyrene and benz $(\alpha)$ anthracene are mainly used as the total PAH emission indicator (concave report no. 98/55.,1998). The levels of PAH in exhaust gas are reported and it is seen that they depend on the type of vehicle, the employed driving cycle and the procedures of sampling and analytical (concave report no. 98/55.,1998). So, it becomes difficult to define the minimum and maximum values (concave report no. 98/55.,1998). The fuel variables which results from the emission of PAHs like fuel aromaticity, the type of aromatic compounds present are also investigated (Zukeran et al.,2017). It is concluded that there is the increase in PAH emission due to the increase in fuel aromaticity, which is "leaded gasoline". This effect was not appeared for the equivalent lead - free fuel quality (Zukeran et al.,2017). Due to their reactivity, the aldehydes are proved to be the precursor of photochemical oxidants. In a study it is also found that the levels of gasoline aldehyde emission is about 6 times lower as compared to the level of aldehyde emission (Zukeran et al.,2017).

\subsection{Methods to control Automobile exhaust}

\section{Diesel Particulate Matter (DPM) control technologies}

The emission from the diesel engine causes harmful impact on humans and ecology. Therefore, to reduce the harmful impact, government has developed some policies for transportation and designed some regulations for the environment to reduce the negative impact by enhancing the fuel economy and considering the environmental performance of the diesel engine (From Kazuichi Hayakawa, Polycyclic Aromatic Hydrocarbons). The new perspective for improving the engine emission is adopted and allowing the manufacturers of the engine to have enough time for implementing the advancement in technology which is important to satisfy the new emission standards (Miller and Facanha.,2014). The wide range 
of emission control technology is applied on the advanced diesel engines and for older diesel engines it is retrofitted (From Kazuichi Hayakawa, Polycyclic Aromatic Hydrocarbons). The technologies which are mainly used for reducing the particulate matter (PM) emissions are diesel particulate filters (DPF), closed crankcase ventilation, diesel oxidation catalysts (DOC) (MECA 2007; IARC., 2014). The technologies like selective catalytic reduction (SCR) and exhaust gas recirculation (EGR) are used to decrease the $\mathrm{NO}_{\mathrm{x}}$ emission (from Kazuich I Hayakawa, Polycyclic Aromatic Hydrocarbons). Generally, these technologies are very helpful in reducing the emission of pollutants like PAHs and NPAHs (Heeb et al, 2008, 2010; $\mathrm{Hu}$ et al, 2013; Khalek et al.,2015). It has been found that various biodiesel blends reduce the emissions of PAHs and NPAHs when it replaces the conventional diesel fuel (Bagley et al, 1998; Sharp et al, 2000). The reduction in the PAH emission is seen from biodiesel up to 65 to $85 \%$ rather than conventional diesel fuel (Bagley et al, 1998).

\section{Electrostatic precipitator with heat exchanger}

The particulate matter like carbon black, soluble organic fraction (SOF) and sulphates are emissions of marine diesels which causes several health problems in humans and coastal environment. ESP (electrostatic precipitator) is made which collect all these particles (Zukeran et al.,2017). ESP has capability to remove the PAHs and it is reported that ESP was able to remove the emission of PAHs from the diesel engine (Phirun et al.,2008). The diesel particulate matter (DPM) which includes sulphates, soluble organic fraction (SOF) and dry soot were removed by ESP having a heat exchanger (Zukeran et al.,2014). Due to the incomplete combustion of fuel, both the soluble organic fraction (SOF) and PAHs are formed. Therefore, the authors were expected that PAHs in gaseous form are absorbed into particulate SOF then condensation takes place in heat exchanger. Thus, there was a collection of PAHs in ESP (Zukeran.,2017) and it was also shown that the PAHs in particulate form, and in gaseous form were removed (Nanjo et al, 2016; Ito et al.,2017).

In an experiment of removing the PAHs in exhaust gas which is emitted from marine diesel, it was found that for eliminating the PAHs in diesel exhaust gas, the electrostatic precipitator with heat exchanger was an effective device (Zukeran.,2017).

\section{Recent Advancements in Removal of PAH}

The PAH emitted from various sources has degraded the ecological system at huge extent. Therefore, several methods have been developed to degrade these harmful toxins environmental pollution. The removal of PAH can be done in various ways like biodegradation method (Abdel-Shafy et al,2014; Perera et al, 2011) chemical degradation and photochemical degradation method. At present by the use of green diesel blending with different diesel we can also reduce carcinogenic PAHs.

\subsection{Biodegradation of PAH}

Biodegradation is an effective method of $\mathrm{PAH}$ degradation around $73 \%$ to $92 \%$ and requires high temperature in the range of 40 to $45^{\circ} \mathrm{C}$ (Adeola and Forbes., 2020). Currently, new developments are made in the field of bioremediation which is thenanoparticle based eco- 
engineered bioremediation method which helps in reducing the compounds like PAH emerging from different sources involving water, soil and sediments (Patel et al.,2020). This technique mainly involves biomolecules like bio-surfactants, humic acids, proteins and enzymes which act as functionalizing agents (Basak et al.,2020). The biodegradation mainly focuses on degrading the PAH present in water sources and soil with the help of several types of plants, microorganisms, and different types of enzymatic reactions (Ghosal et al.,2016., Gouma, Fragoeiro, Bastos and Magan, 2014). Biodegradation is considered as a meticulous field of research. However, there is a need for some advancement for some microbial bioremediation (Ghosal et al.,2016). The PAH affects differently from each process due to the difference in the structure of PAH and their biological, physical and chemical properties (Abdel-Shafy and Mansour.,2016). The removal of PAH from the contaminated environment can also be done by the help of bio functionalized NPs which has properties like catalytic degrading and nano - adsorption (Basak et al.,2020). The silica nanoparticles which are coated with zwitterionic lipid bilayers are used to degrade the benzo $(\alpha)$ pyrene from the contaminated surface and soil's subsurface (Wang et al., 2015).

A recent advancement in the field of microbial biology has been achieved. This achievement mainly focuses on identifying conserved sequences, which is found in the particular microorganism's group, mainly $16 \mathrm{~S}$ rRNA and $18 \mathrm{~S}$ rRNA genes. They mainly provides the phylogenetic characterization which is present in the habitat of the microbial population (Pace et al.,1986; Amann et al.,1995). This technique proves to be effective in the area of treating PAH through bioremediation approach because it becomes easier to find out the microorganisms which live in those environments by finding the microbiota in the polluting system, and therefore it is possible to predict the biodegradation potential (Ghosal et al.,2016). Currently, it is seen that the bacteria like Aeromonas hydrophila, Serratia marcescens, Bacillus megaterium and Raoultella are capable of degrading the PAH like acenaphthene and fluorene up to $90 \%$ (Ghosal et al., 2016). The two types of bioremediation approaches involve in situ (or the intrinsic bioremediation) of micro flora dwelling at the place which is having contamination of various pollutants and based on its bioremediation potential (Ghosal et al.,2016). This technique is the most efficient option due to little disturbances and cheap rate, also avoid digging and provides the remediation at its main site (Ghosal et al.,2016). On other side ex situ (or extrinsic bioremediation involves physically eliminating the polluted material for the treatment to another place (Carberry and Wik, 2001). The fungi and bacterial species can also degrade the PAH in large proportion. The fungi like Peniophora gigantea, Pycnosporus coccineus, Phanerochaete chrysosporium and Trametes versicolor (Silva, Grossman and Durrant, 2009) and bacteria are like Trichocladium sp., Fusarium sp., Pseudomonas and Aspergillus (Quinn et al,2009; Soleimani,2012; Sun et al,2014; Wu, Chen, Tian, Ding and Dick, 2013) effectively degrade the pollutants like PAHs.

The factors like temperature and $\mathrm{pH}$ are capable of changing the efficacy in the process of bioremediation. However, due to enhancement in the microbial growth the temperature in the range of $30^{\circ}$ to $38^{\circ} \mathrm{Care}$ considered as optimum for degrading the $\mathrm{PAH}$. The decrease in the amount of dissolved $\mathrm{O}_{2}$ which is available in the bioreactor for the microbial growth is seen, when there is a reduction in the solubility of oxygen due to increasing temperature (Alegbeleye et al.,2017; Vinas, Sabate, Espuny and Solanas, 2005). The bioavailability is the main factor for degrading the PAH by bacteria and it becomes bioavailable in the dissolved or vapour phase (Abdel-Shafy and Mansour.,2016). The solubility also plays an important 
role for bioavailability of PAH (Abdel-Shafy and Mansour.,2016). However, the degradation in the rate of PAH experiences the reduction if the chemical found by the degrading bacteria, which is better used as a food source (Abdel-Shafy and Mansour., 2016).

\section{Degradation by bacteria}

The bacteria are considered as the natural scavengers as they are capable of developing the methods for obtaining the energy from virtually each and every compound and evolved around three billion years ago or more (Ghosal et al., 2016). The bacteria can be considered as the remediation for degrading environmental hazards because of their quick flexibility (Ghosal et al., 2016). The bacteria like gram-positive and gram-negative can be easily isolated from soil which have the ability to metabolize naphthalene, anthracene and phenanthrene (Figure 7) (Cerniglia, 1993). It has been seen that the soils with low PAH content contain low PAH utilizers than soils with high total PAH content $\left(10^{5}-10^{10}\right.$ bacteria per gram of soil) (Cerniglia., 1993).

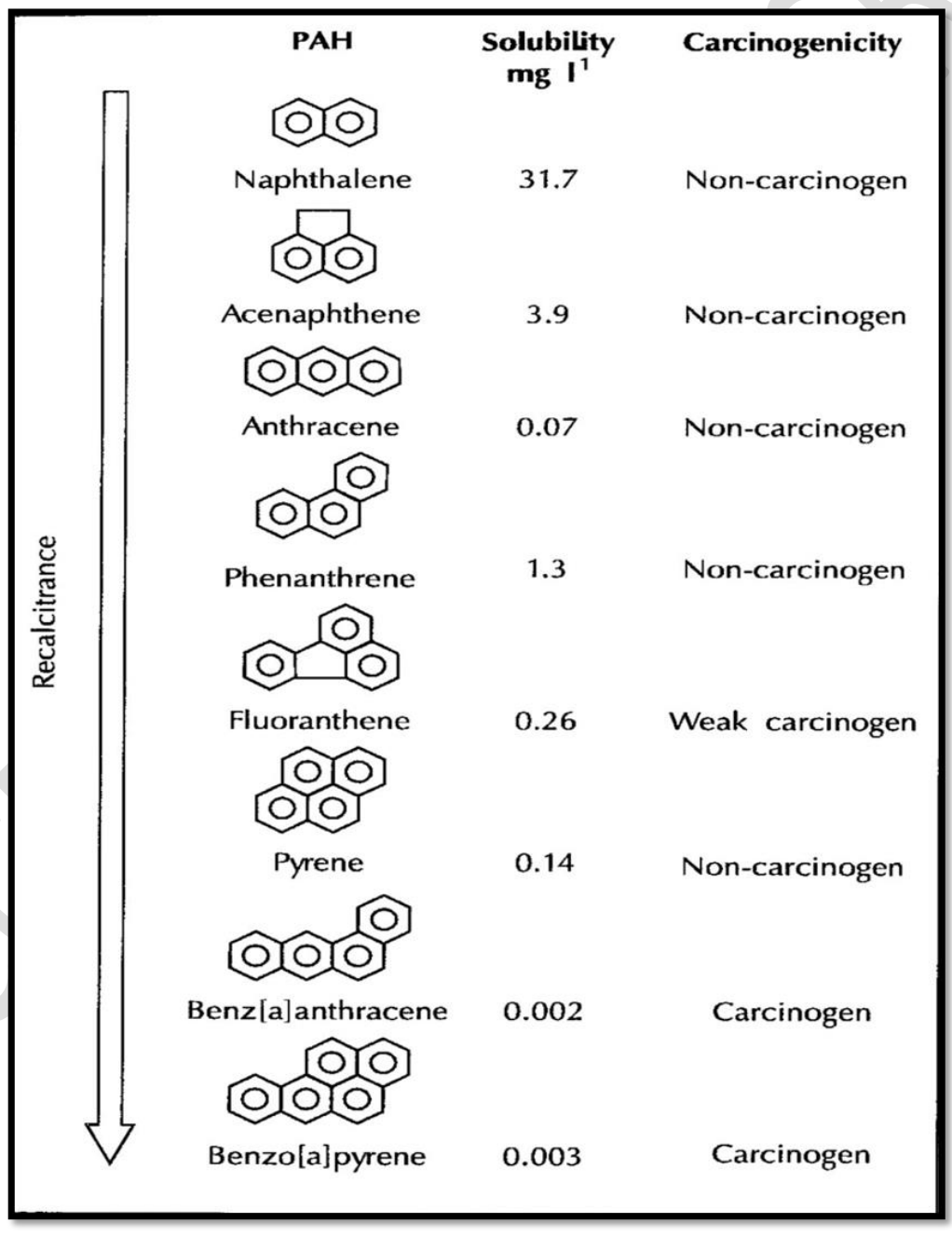

Figure 7. Structural formulas, solubilities and carcinogenicity of polycyclic aromatic hydrocarbons (Cerniglia, 1993). 
On the basis of oxygen's presence or absence, there are mainly two ways for degrading the bacteria (Ghosal et al.,2016). The aerobic bacterial PAH degradation initiates when the $\mathrm{O}_{2}$ act as the final electron acceptor and for hydroxylation co-substrate and oxygen-mediated cleavage of aromatic ring (Chen et al.,2016). The anaerobic PAH degradation mainly depend on the alternative final electron acceptor and reductive reaction type for breaking and opening of the aromatic ring) (Dhar et al.,2020; Ghosal et al.,2016). The degradation of bacteria mainly initiates from the attack of dioxygenases on the aromatic ring and form a compound named cis-dihydrodiol (Fig 2). The formation of trans-dihydrodiols by monooxygenases oxidation has been shown (Heitkamp et al.,1998; Kelley et al.,1991). The compound formed by dihydroxylation i.e cis-dihydrodiol intermediate on oxidation to form substrates for ring cleavage enzymes and on doing catabolism generates tricarboxylic acid cycle intermediates (Cerniglia., 1993).

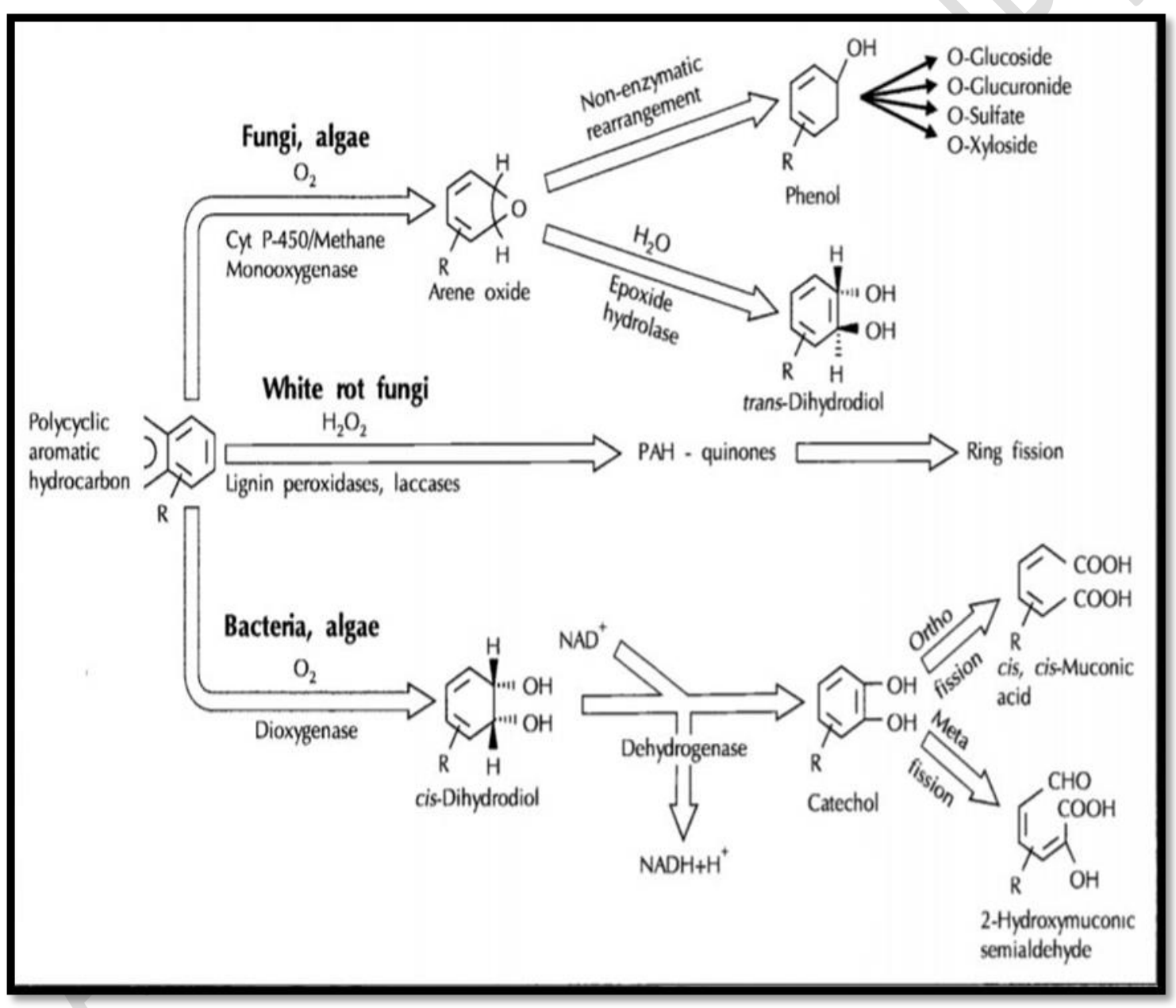

Figure 8 . The steps involved in microbial pathways for oxidation of polycyclic aromatic hydrocarbons (Cerniglia., 1993).

\section{Degradation by fungi}

For the biodegradation of PAH contaminated soil, the fungi are equally important as bacteria (Cerniglia, 1993). There are very few studies on PAH degradation by fungi as compared to bacteria (Lawal., 2017). Unlikely, fungi do not use PAH as the main source of carbon and energy, but they transform the PAH co-metabolically to the chemical products which are detoxified (Cerniglia, 1993). The fungal transformation by PAH includes different paths 
initiated by enzymes and also depends on the specific species and growth factor (Ghosal et al.,2016). There are mainly two types of fungi which are involved in PAH biodegradation (Ghosal et al., 2016). The ligninolytic fungi or white - rot fungi (which have the capability to produce several enzymes like lignin peroxidase (Lip), laccases and manganese peroxidase (MnP) for the degradation of lignin present in wood) and second is non-ligninolytic fungi( which do not have the ability to produce enzymes like peroxidases and laccases, but have the ability to produce enzymes like cytochrome P450 monooxygenases (Hofrichter, 2002; Cerniglia and Sutherland, 2010; Tortella et al.,2005; Li et al.,2010). After the catalytic cleaving of aromatic compounds, the ligninolytic enzymes produce polar products which are water soluble which then available for the soil microflora and the fungal metabolism present in the vicinity (Gupta and Pathak, 2020). Some of the fungal species have the ability to produce the bio surfactants which can reduce the hindrance for high molecular weight PAH which are less soluble, and it results in degradation at maximum level (Ojha et al., 2019).

\section{Degradation by Algae}

The biodegradation of PAH by algae has gain less attention as compared to biodegradation with bacteria and fungi (Ghosal et al., 2016). For the aquatic environment, the microalgae are commonly known as the primary producers and play an important role for degrading the PAH in an aquatic environment (Ghosal et al., 2016). The microalgae (Cyanobacteria) which is a freshwater single celled green alga considered as prominent due to its propagating nature, the ubiquitous occurrence and most effective for degrading HMW PAHs (Ke et al, 2010). It has also been shown that under photoautotrophic conditions, in the presence of little amounts of cis - 1,2-dihydroxy - 1,2- dihydronapthalene and 4-hydroxy-1-tetralone, the cyanobacteria and green, red and brown algae oxidize naphthalene to 1-naphthol (Cerniglia et al.,1980). The cellular biodegradation and bioaccumulation are mainly responsible for the algae-mediated effective PAH removal (Ke et al.,2010).

\section{Degradation by archaea}

Harmful pollutants, PAH and petroleum-based pollutants are released by some oil industries mainly in the saline region and requires extremophiles for bioremediation and not the conventional microorganisms (Dastgheib et al.,2012). Recently, there are various reports in which the archaea can degrade the PAH effectively. In a study it is seen that the distribution is mainly in six groups of the archaeal and bacterial strains which are having the catabolic property (Ghosal et al., 2016). The groups are mainly Betaproteobacteria, Alphaproteobacteria, Gammaproteobacteria, Firmicutes Actinomycetes and Archaea (Halophiles) (Ghosal et al., 2016).

\subsection{Photodegradation of PAHs}

The boiling point of PAHs varies in between 300 to $1000^{\circ} \mathrm{C}$. In this method, the degradation of the compound is done in the presence of light (Manahan., 1994). The reactions mainly initiated when there is excitation of electrons by the absorption of light through the PAH within the molecule. However, these type of excitations generate the arrangements which are not the stable structure (Abdel-Shafy and Mansour, 2016) and they allow various types of 
processes involving physical and chemical to act on these compounds (Schwarzenbach et al., 1993). Some of the little photodegradation can also occur when the PAHs are stick to the particles present in the atmosphere or in soil which gives the reactions which is more active and having the increment in the particle surface area (Okoro et al.,2020). With the help of the catalyst like $\mathrm{TiO}_{2}$ (titanium oxide) and UV radiation, the PAH degradation with the help of photocatalysis is investigated (Zhang, Li, Gong and Li.,2008). The PAH like phenanthrene, benzo $(\alpha)$ pyrene and pyrene follows the path of pseudo- first order in the presence of UV irradiation and due to its catalytic activity by adding some amount of $\mathrm{TiO}_{2}$ the reaction was accelerated (Garg et al., 2019). Under different UV radiation intensities various types of PAHs are degraded to different extents whereas the increase in the dosage of $\mathrm{TiO}_{2}$ from 0.5 to 3 weight percent has no significant result on the photo degradation of $\mathrm{PAH}$ and which is mainly high under the acidic conditions of $\mathrm{pH}$ (Zhang et al.,2008). The reactions of photolysis are effective on the particles like silica gel and alumina which are light coloured particles in comparison with the dark colour particles like carbon black. For instance, the half life of anthracene on alumina is $0.5 \mathrm{~h}$ whereas on carbon black is $310 \mathrm{~h}$ (Abdel-Shafy and Mansour.,2016). The photo degradation approach is considered as more effective for the low molecular weight compounds like naphthalene because of the high bioavailability and also for a long period of time they can be exposed to sunlight, (Okoro et al.,2020). The PAH photo degradation in the soil mainly depend on hydrocarbon molecular weight, the texture of the soil and the overall exposure time (Marques et al.,2016).

Generally, the angular PAHs like dibenz[$[\alpha, h]$ anthracene, anthracene and the phenanthrene show slow process of degradation while the two membered ring and linear and some PAHs which form clusters exhibit fast degradation in the presence of light. This change in the rate of degradation is mainly because they are having the most stable structure (Korfmacher et al., 1980). The composites which are having the photocatalytic properties are synthesized and they applied for the degradation of $\mathrm{PAH}$ (e.g like platinum / $\mathrm{TiO}_{2}{ }^{-} . \mathrm{SiO}_{2}$ ) (Luo et al., 2015).

\subsection{The Chemical Degradation of PAHs}

In various environmental conditions, the chemical oxidation is considered as a little process of PAH degradation (Abdel-Shafy and Mansour, 2016). This technology mainly uses the oxidants like activated persulfate (Huling and Pivetz, 2006), ozone (Lian et al, 2017), Fenton reagent (Zhang, Dong, Zhao, Wang and Meng, 2019) and $\mathrm{H}_{2} \mathrm{O}_{2}$ (Flotron, Delteil, Bermond and Camel, 2005). There are some species which are greatly responsible for the PAHs aromatic ring breakdown and these techniques involve the generation of some reactive radicals like $\cdot \mathrm{OH}, \mathrm{O}_{3}$ and some of the reactive species like peroxides and persulfate anion (Adeola and Forbes, 2020). The different degradation ways are such that different oxidation reactions which involves the $\cdot \mathrm{OH}$ radical and $\mathrm{O}_{3}$ are willing to react with aromatic compounds like PAHs at very near diffusion-controlled rates by the abstraction of $\mathrm{H}$-atom or by two fold bonds expansion (Ukiwe et al., 2013). The reaction further proceeds with various complex ways and creating different intermediates (Agrawal et al., 2019). In these types of reaction, the final product involve mixture of quinones, aldehydes, carboxylic acids and ketones for both the oxidants (Reisen and Arey, 2002). $\mathrm{O}_{3}$ can directly attack double bonds or it can form $\cdot \mathrm{OH}$ reactive radical (who can attack on double bonds) by decomposition of water (Legrini, Oliveros and Braun, 1993). It is also investigated that some of the treatments like 
physical and chemical, have the ability to degrade the PAHs from the surface water in huge extent (Ukiwe et al.,2013). The degradation of PAHs by the photo chemical method involves similar oxidative species that are generated during PAH through pure chemical oxidation (Ukiwe et al.,2013). Due to the presence of high radical reactivity and degradation of in situ contaminants the quality of chemical oxidation in comparison with other conventional methods of remediation involve shorter treatment time and effectiveness for the broad range of PAH remediation (Adeola and Forbes, 2020).

Due to the low aqueous solubility and vapour pressure, the chemical degradation efficiency of PAHs is limited (Luning and Pritchard, 2002). Therefore, the surfactants are considered as an effective tool that are having the properties for removing the problem of low aqueous solubility of PAH (Boonchan, Britz and Stanley,1998). Different studies also focus on the importance of the surfactants in order to increase PAHs solubility by lowering down the interfacial surface tension between the PAH and water-soil interface (Li and Chen,2009).

\subsection{Phytodegradation of PAHs}

The phytodegradation of PAHs is the approach in which the plants and soil microorganisms are used for minimizing the concentration and the hazardous effects of the contaminants like PAHs in the atmosphere (Lawal.,2017). It is in situ and solar energy regulated approach which also minimizes the cost (Haritash and Kaushik, 2009). Many researchers have investigated that several different types of grasses and leguminous plants have a good ability for the phytodegradation (Ukiwe et al., 2013). Several types of categories of grasses like Boutelouagracilis, Elymus canadensis, Festuca rubra, Festuca arundinacea, Agropyron smithii, Melilotus officinalis and Cynodon dactylon etc are commonly studied for degrading the PAHs (McCutcheon and Schnoor,2003). The sources of energy and carbon which are used by the plants are sunlight and carbon dioxide. The roots of the plants are capable of absorbing a variety of natural and hazardous compounds from human as well as industrial activities and for which several amazing methods of detoxification have developed (Lawal, 2017). In a study it is also found that the grasses like tall fescue (Festuca arundinacea) and switch grass (Pannicum virgatum) have the ability to degrade the PAH like pyrene about $38 \%$ in 190 days (Chen, Banks and Schwab, 2003). Some authors also found the significant enhancement in the PAHs adsorption from the contaminated soil in the presence of vegetation such as corn (Zea mays), rape seed (Brassica napus) and alfalfa (Medicago sativa) (Ukiwe et al., 2013). By releasing enzymes through roots, the plants remove the PAHs in an indirect manner (Agrawal et al., 2019). By catalysing the chemical reactions in soil, the enzymes have the capability for transforming the organic contaminants (Ndimele et al., 2010). Thus, it is considered that phytoremediation is an emerging technology for the degradation of PAHs (Sun, Cang et al., 2010).

\subsection{Degradation by Adsorption process}

The adsorption is considered as the surface phenomenon at which the pollutants are adsorbed onto the surface or the interface through different types of attractive forces like physical, chemical and electrostatic (Adeola and Forbes.,2020). The processes which influence the adsorption of organic compounds are $\mathrm{pH}$, temperature, sorbate concentration, particle and 
pore size and various adsorbate and adsorbent physicochemical properties (Adeola and Forbes.,2020). The adsorption technique is simple, quick, require a minimum amount of solvent and have high recovery and due to this reason, it is used for the PAH removal from water samples (Ma et al.,2010). In this process, the nature of adsorbent is considered as an important factor of obtaining the best results (Adeola and Forbes.,2020). The materials which act as adsorbents for the removal of PAH and pre-concentration in contaminated water are the porous organoclay composite, polyvinylidene fluoride, bamboo charcoal and matriximmobilized organoclay (Ma et al.,2010). Although, there is need for the improvement in the recovery of PAHs having high ring (Ma et al.,2010). This technique has various advantages which involves the removal of hazardous compounds produced by processes like oxidation and reduction, rather than broken into harmful metabolites (Okoro et al.,2020). However, for the adsorption treatment of wastewater containing PAHs, activated charcoal is proved to be very effective adsorbent (Okoro et al., 2020).

\subsection{PAHs removal through filtration in wastewater}

The process which is capable of removing solutes from fluids through a filter which act as a medium and allows the fluid to cross and keep the solutes is called filtration (Akinpelu et al., 2019). The process can be physical, mechanical and biological. The passing fluid through the filter is termed as filtrate (Akinpelu et al., 2019). Recently, for the removal of PAH by the filtration process, the membrane is considered as a common medium. The size of the particles which is retained on the medium (membrane) are the application of different procedures of filtration (Akinpelu et al., 2019). The particle size of PAHs is very small as compared to the microfiltration membranes (MF) pore size, therefore microfiltration is not considered for the removal of PAHs (Smol and Wlodarczyk - Makula, 2016). Thus, the procedures like forward osmosis (FO), ultrafiltration (UF), nano filtration (NF), reverse osmosis (RO) are considered as most convenient procedures for the removal of PAHs which is applied in filtration (Akinpelu et al.,2019).

\section{Future prospective}

There is a need of research in the area of automobile exhaust which is a major source of PAH. There is a need for advancement in the technologies which are capable of reducing the diesel exhaust. However, the electrostatic precipitator with heat exchanger proved to be effective for the PAHs removal in diesel exhaust, but the removal technologies for PAHs from automobile exhaust could be an appealing topic for near future research (Zukeran et al., 2017). The progress in the field of bioremediation has been made as discussed above. Various technologies and remediation approaches have been developed. Although, several challenges are unresolved and also the remediation of the site of PAHs is an enormous task. From this review, we cannot deny the fact that the bioremediation, photoremediation are the most effective methods which provides a considerable solution of the degradation of PAH. The conventional treatments like phytoremediation are proved to be a refreshing method for PAHs treatment. There is a need for research in the degradation of PAH under soil and the huge problems which have to look upon is the marine environment. There is a need to determine, what is exactly happening in the environment which is contaminated with PAHs. There is very little information on enzymes, genes, and also on the molecular mechanism of 
the PAHs degradation in the high- salty environment and anaerobic or low- oxygen containing environments (Ghosal et al., 2016).

For the many preceding years, degradation of PAHs by different microorganisms has been studied. However, very limited work has been dedicated to most carcinogenic PAH BaP, and the main purpose is its recalcitrance to biodegradation, as the result of its high stability. However, a few studies have been devoted on $\mathrm{BaP}$ biodegradation. For instance, so far, there is no report on a single bacterial strain that can biomineralise $\mathrm{BaP}$ when used as a sole source of carbon. More studies are needed on individual PAH according to their carcinogenicity report.

\section{Conclusion}

The PAH are the compounds which come under the class of unregulated pollutants. Several authors found that the greatest source of PAH is automobile exhaust, which is also responsible for lung cancer in humans. From the literature review it is also found that automobile exhaust which also causes air pollution, is highest in the winter season. The PAH and NPAH are the main class of compounds and are largely emitted from the incomplete combustion of diesel engine. However, the diesel particulate matter technologies (DPM) are helpful in reducing the PAH contaminant by increasing the fuel economy. Several technologies like diesel particulate filters, diesel oxidation catalysts (DOC) and closed crankcase ventilation is used for reducing the particulate matter (PM) emission. The electrostatic precipitator with heat exchanger is helpful in removing the PAH emitted from marine diesel up to a large extent. The advancement in the biodegradation of PAH is also shown and it is found by several authors that this technique is effective with the degradation up to 72 to $92 \%$. The phytoremediation is considered as cost effective technique. The adsorption and photoremediation also proved to be a productive one. The adsorption processes are having a lot of advantages and involves removal of harmful compounds rather than broken into metabolites. The advancement in several PAH degradation techniques are helpful in degrading the PAH up to a maximum level while phytoremediation can be a revolutionized topic for near future research.

\section{References}

A. Zukeran, Y. Nanjo, K. Ito and T. Inui. (2017). 'Removal of polycyclic aromatic hydrocarbons emitted from diesel engine using an electrostatic precipitator and heat exchanger'. IEEE Industry Applications Society Annual Meeting, 2017, pp. 1-6, https://doi.org/10.1109/IAS.2017.8101687

A. Zukeran, Y. Sakuma, R. Yamagami, Y. Kawada, H. Kawakami, K. Yasumoto, T. Inui, Y. Ehara, (2014)., "The effect of gas cooling on removal of SOF and sulphate by electrostatic precipitator for marine diesel", WIT Transaction on Ecology and The Environment, Vol. 183, pp. 165-176, https://doi.org/10.2495/AIR14014 
Abdel-Shafy H. I., Al-Sulaiman A. M., Mansour M.S.M. (2014). 'Greywater treatment via hybrid integrated systems for unrestricted reuse in Egypt'. J Water Process Eng 1, 101-107., https://doi.org/10.1016/j.jwpe.2014.04.001

Abdel-Shafy, H. I., and Mansour, M. S. (2016). 'A review on polycyclic aromatic hydrocarbons: source, environmental impact, effect on human health and remediation'. Egypt. J. Pet. 25, 107-123. https://doi.org/10.1016/j.ejpe.2015.03.011

ACGIH (American Conference of Governmental Industrial Hygienists). Polycyclic aromatic hydrocarbons (PAHs) biologic exposure indices (BEI) Cincinnati. OH: American Conference of Governmental Industrial Hygienists; 2005.

Adeola, A. O., and Forbes, P. B. C. (2020). 'Advances in water treatment technologies for removal of polycyclic aromatic hydrocarbons: Existing concepts, emerging trends, and future prospects'. Water Environ. Res. 9, 343-359. https://doi.org/10.1002/wer.1420

AGENCY FOR TOXIC SUBSTANCES AND DISEASE REGISTRY. (1994)., 'Toxicological profile for polycyclic aromatic hydrocarbons (PAHs)': update. Atlanta, GA, US Department of Health and Human Services, Public Health Services

Agrawal P. K., Shrivastava R., Verma J. (2019). 'Bioremediation Approaches for Degradation and Detoxification of Polycyclic Aromatic Hydrocarbons'. Emerging and Eco- Friendly Approaches for Waste Management. Springer, Singapore. https://doi.org/10.1007/978-981-10-8669-4_6

Air quality guidelines for Europe. 2nd ed. Copenhagen: WHO Regional Office for Europe; 2000. Polycyclic aromatic hydrocarbons. (WHO Regional Publications, European Series, No. 91)

Akinpelu A. A., Ali M. E., Johan M.R., Saidur R., Qurban M. A., Saleh T. A. (2019). 'Polycyclic aromatic hydrocarbons extraction and removal from wastewater by carbon nanotubes: A review of the current technologies, challenges and prospects. Process Saf Environ. Elsevier, 122, 68-82., https://doi.org/10.1016/j.psep.2018.11.006

Alebic-Juretic A., Cvitas T., Klasinc L., Heterogeneous polycyclic aromatic hydrocarbon degradation with ozone on silica gel carrier. (1990)., Environ. Sci. Technol, 24, 62-66., https://doi.org/10.1021/es00071a005

Alegbeleye O. O., Opeolu B.O., Jackson V. (2017). 'Bioremediation of polycyclic aromatic hydrocarbons (PAH) compounds $\odot$ acenaphthene and fluorene) in water using indigenous bacterial species isolated from the Diep and Plankenburgrivers'. Western Cape, South Africa, Braz. J. Microbiol., 48, 314-325., https://doi.org/10.1016/j.bjm.2016.07.027

Amann R. I., Ludwig W., Schleifer K. H. (1995). 'Phylogenetic identification and in situ detection of individual microbial cells without cultivation'. Microbiol. Rev, 59, 143-169., https://doi.org/10.1128/mr.59.1.143-169.1995 
Araki, Y., Tang, N., Ohno, M., Kameda, T., Toriba, A., Hayakawa, K. (2009). 'Analysis of atmospheric polycyclic aromatic hydrocarbons and nitropolycyclic aromatic hydrocarbons in gas/particle phases separately collected by a high-volume air sampler equipped with a column packed with XAD-4 resin'. J. Health Sci. 55(1), 77-85. https://doi.org/10.1248/jhs.55.77

Armstrong, B., Hutchinson, E., Unwin, J., and Fletcher, T. (2004). 'Lung cancer risk after exposure to polycyclic aromatic hydrocarbons: a review and metaanalysis'. Environ Health Perspect. 112(9), 970-978. https://doi.org/10.1289/ehp.6895

Bach, P. B., Kelley, M. J., Tate, R. C., and McCrory, D. C. (2003). 'Screening for lung cancer: a review of the current literature'. Chest. 123, 72-82. https://doi.org/10.1378/chest.123.1_suppl.72s

Bagley S.T, Gratz L.D, Johnson J.H, McDonald J.F. (1998), 'Effects of an oxidation catalytic converter and a biodiesel fuel on the chemical, mutagenic, and particle size characteristics of emissions from a diesel engine'. Environ Sci Technol 32(9):11831191

Bandowe, B. A. M., and Nkansah, M. A. (2016). 'Occurrence, distribution and health risk from polycyclic aromatic compounds (PAHs, oxygenated-PAHs and azaarenes) in street dust from a major West African Metropolis'.Sci Total Environ. 553, 439449.https://doi.org/10.1016/j.scitotenv.2016.02.142

Basak G., Hazra C., Sen R. (2020).'Biofunctionalized nanomaterials for in situ cleanup of hydrocarbon contamination: a quantum jump in global bioremediation research'. Environ. Manage, 256, 1-20., https://doi.org/10.1016/j.jenvman.2019.109913

Bjorseth, A., and Lunde, G. (1979). 'Long-range transport of polycyclic aromatic hydrocarbons'. Atmos. Environ. 13(1),45-53. https://doi.org/10.1016/0004$\underline{6981(79) 90243-9}$

Bodzek, D., Luks-Betlej, K., and Warzecha, L. (1993). 'Determination of particle associate polycyclic aromatic hydrocarbons in ambient air samples from the Upper Silesia region of Poland'. Atmos. Environ. A, Gen. Top. 27(5),759-764. https://doi.org/10.1016/0960-1686(93)90193-3

Bomboi, M. T., and Hernández, A. (1991). 'Hydrocarbons in urban runoff: Their contribution to the wastewaters'.Water Res. 25(5), 557565.https://doi.org/10.1016/0043-1354(91)90128-D 
Boonchan S., Britz M. L. (1998). 'Stanley G. A., Surfactant enhanced biodegradation of high molecular weight polycyclic aromatic hydrocarbons by Stenotrophomonas maltophilia'. BiotechnolBioeng, 59, 482-494., https://doi.org/10.1002/(sici)10970290(19980820)59:4<482::aid-bit11>3.0.co;2-c

Carberry J.B., Wik J., Comparison of ex situ and in situ bioremediation of unsaturated soils contaminated by petroleum. (2001)., J. Environ. Sci. Health A Tox. Hazard. Subst. Environ. Eng. 36, 1491-1503., https://doi.org/10.1081/ESE-100105726

Cerniglia C. E., Sutherland J. B. (2010). 'Degradation of Polycyclic aromatic hydrocarbons by fungi', in Handbook of Hydrocarbon and Lipid Microbiology, eds Timmis K. N., McGenity T. J., Van der Meer J. R., Lorenzo V. de (Berlin:Springer),, 2080-2110. https://doi.org/10.1007/978-3-540-77587-4_151

Cerniglia C.E., Gibson D.T., Van Baalen C. (1980) 'Algal Oxidation of Naphthalene J Gen Microbiol'., 116:495-500. https://doi.org/10.1099/00221287-116-2-495

Cerniglia C.E. (1993). 'Biodegradation of polycyclic aromatic hydrocarbons'. Curr. Opin. Biotechnol., 4, 331-338., https://doi.org/10.1016/0958-1669(93)90104-5

Chan S. M. N., Luan T., Wong M. H., Tam N. F. Y. (2006). 'Removal and biodegradation of polycyclic aromatic hydrocarbons by Selenastrum capricornutum'. Environ. Toxicol. Chem, 25, 1772-1779.,https://doi.org/10.1897/05-354r.1

Chen B., Huang J., Yuan K., Lin L., Wang X., Yang L. (2016). 'Direct evidences on bacterial growth pattern regulating pyrene degradation pathway and genotypic dioxygenase expression'. Mar. Pollut. Bull, 105, 73-80., https://doi.org/10.1016/j.marpolbul.2016.02.054

Chen Y. C., Banks M. K., Schwab A. P. (2003). 'Pyrene degradation in the rhizosphere of tall fescue (Festuca arundinacea) and switchgrass (Panicum Virgatum)'. Environ Sci Technol, 37, 5778-5782., http://dx.doi.org/10.1021/es030400x

Dastgheib S. M. M., Amoozegar M. A., Khajeh K., Shavandi M., Ventosa A. (2012). 'Biodegradation of polycyclic aromatic hydrocarbons by a halophilic microbial consortium'.Appl. Microbial. Biotechnol, 95, 789-798., https://doi.org/10.1007/s00253-011-3706-4

de Vos, R. H., van Dokkum, W., Schouten, A., and de Jong-Berkhout, P. (1990). Polycyclic aromatic hydrocarbons in Dutch total diet samples (1984-1986),Food Chem. Toxicol. 28(4), 263-268.https://doi.org/10.1016/0278-6915(90)90038-O 
Dean, J. R., and Xiong, G. (2000). 'Extraction of organic pollutants from environmental matrices: Selection of extraction technique'. Trends Anal. Chem. 19(9),553-564. https://doi.org/10.1016/S0165-9936(00)00038-8

Dhar K., Subashchandrabose S. R., Venkateshwarlu K., Krishnan K., Megharaj M. (2020). 'Anaerobic microbial degradation of polycyclic aromatic hydrocarbons: a comprehensive review'. Rev. Environ. Contam. T, 251, 25-108., https://doi.org/10.1007/398_2019_29

Dickhut R. M., Canuel E. A., Gustafson K. E., Liu K., Arzayus K. M., Walker S. E., Edgecombe G., Gaylor M. O., Macdonald E. H. (2000). 'Automotive Sources of Carcinogenic Polycyclic Aromatic Hydrocarbons Associated with Particulate Matter in the Chesapeake Bay Region'. Environ. Sci. Technol., 34, 4635-4640., https://doi.org/10.1021/es000971e

Doll R. and Peto R. (1981); 'The causes of cancer: quantitative estimates of avoidable risks of cancer in the United States'. J. Natl. Cancer Inst. 66, 11911308.https://doi.org/10.1007/978-1-4757-1117-2_30

Doel R., Jorgensen R., King D. J., Mann N., Scorletti P. (1998).'Polycyclic Aromatic Hydrocarbons in automotive exhaust emissions and fuels'. concave.

EPA US., (2002).,Health assessment document for diesel engine exhaust. US EPA, Washington, $D C$

E. Stanley Manahan, (1994)‘Environmental chemistry’, CRC Press Inc.

Efroymson R., Alexander M. (1991).'Biodegradation by an Arthrobacter Species of Hydrocarbons Partitioned into an Organic Solvent'.Appl Microbiol Biotechnol, 34, 804-808., https://doi.org/10.1128/aem.57.5.1441-1447.1991

Escriva, C., Viana, E., Molto, J. C., Pico, Y., and Manes, J. (1994). 'Comparison of four methods for the determination of polycyclic aromatic hydrocarbons in airborne particulates'. J. Chromatogr. A. 676(2), 375-388. https://doi.org/10.1016/00219673(94)80438-9

Flotron V., Delteil C., Bermond A., Camel V., (2005) Degradation of polycyclic aromatic hydrocarbons in sewage sludges by Fenton's reagent. In E. Lichtfouse, J. Schwarzbauer, D Robert (Eds), Environmental Chemistry: Green Chemistry and Pollutants in Ecosystems (pp, 449-459). Berlin Heidelberg, Berlin, Heidelberg: Springer., https://doi.org/10.1016/j.jhazmat.2007.03.057

Furton, K. G., Jolly, E., and Pentzke, G. (1993). 'Recent advances in the analysis of polycyclic aromatic hydrocarbons and fullerenes'. J. Chromatogr. A. 642(1-2),33-45. https://doi.org/10.1016/0021-9673(93)80074-I 
Garg A., Singhania T., Singh A., Sharma S., Rani S., NeogyA., Garg N.(2019). 'Photocatalysis degradation of bisphenol- A using N, Co co-doped TiO2 catalyst under solar light'. Sci. Rep, 9(765), 1-13., https://doi.org/10.1038/s41598-018-38358$\underline{\mathrm{W}}$

Ghosal D., Ghosh S., Dutta T. K., Ahn Y. (2016). 'Current State of Knowledge in Microbial Degradation of Polycyclic Aromatic Hydrocarbons (PAHs): A Review'. FRONT MICROBIOL., 7:1369., https://doi.org/10.3389/fmicb.2016.01369

Gouma S., Fragoeiro S., Bastos A. C., Magan N. (2014). 'Bacterial and fungal bioremediation strategies. In S. Das (Ed.), Microbial biodegradation and bioremediation. 13, (pp. 301-323). Oxford, UK; Elsevier.

Grifoll M., Casellas M., Bayona J. M., Solanas A. M. (1992). 'Isolation and Charaterization of a Fluorene-Degrading Bacterium: Identification of Ring Oxidation and Ring Fission Products'. Appl Environ Microbiol, 58, 2910-2917., https://doi,org/10.1128/aem.58.9.2910-2917.1992

Grossi, G., Lichtig, J., and Kraul, P. (1998). 'PCDD/ F, PCB and PAH content of Brazilian compost'. Chemosphere. 37(9-12),2153-2160. https://doi.org/10.1016/s0045-6535(98)00277-x

Gupta H. (2015). 'Removal of phenanthrene from water using activated carbon developed from orange ring'. Int. J. Sci. Res. Environ. Sci, 3, 248-255., https://doi.org/10.12983/ijsres-2015-p0248-0255

Gupta S., Pathak B., (2020) "Mycoremediation of polycyclic aromatic hydrocarbons", in Abatement of Environmental Pollutants, eds A. Borthakur, P. Singh, A. Kumar (Amsterdam: Elsevier), 127-149., https://doi.org/10.1016/b978-0-12-818095-2.00006$\underline{0}$

Gupte, A., Tripathi, A., Patel, H., Rudakiya, D., and Gupte, S. (2016). 'Bioremediation of polycyclic aromatic hydrocarbon (PAHs): a perspective'. Open Biotechnol. J. 10, 363-378. http://dx.doi.org/10.2174/1874070701610010363

Gurol M. D., Singer P. C., Kinetics of ozone decomposition: A dynamic approach. (1982). Environ. Sci. Technol, 16, 377-383., https://doi.org/10.1021/es00101a003

Haritash A. K., Kaushik C. P. (2009). 'Biodegradation aspects of polycyclic aromatic hydrocarbons (PAHs) : a review’. J Hazard Mater 169(1-3): 1-15., https://doi.org//10.1016/j.jhazmat.2009.03.137

Harner, T., Su, K., Genualdi, S., Karpowicz, J., Ahrens, L., Mihele, C., Schuster, J., Charland J. P., and Narayan, J. (2013). 'Calibration and application of PUF disk passive air samplers for tracking polycyclic aromatic compounds (PACs)'. Atmos. Environ. 75, 123-128. https://doi.org/10.1016/j.atmosenv.2013.04.012 
Havenga, W. J., and Rohwer, E. R. (2000). 'The use of SPME and GC-MS for the chemical characterisation and assessment of PAH pollution in aqueous environmental samples'. Int $J$ Environ Anal Chem .78(3-4),205-221. https://doi.org/10.1080/03067310008041342

Hayakawa, K. (2000). 'Chromatographic methods for carcinogenic/mutagenic nitropolycyclic aromatic hydrocarbons'. Biomed Chromatogr. 14(6),397-405. https://doi.org/10.1002/1099-0801(200010)14:6\%3C397::aid-bmc27\%3E3.0.co;2-o

Hayakawa K, Tang N, Kameda T, Toriba A. (2014).,'Atmospheric behaviors of polycyclic aromatic hydrocarbons in East Asia'. Genes Environ 36(3):152159https://doi.org/10.3123/jemsge.2014.016

Heeb N.V, Schmid P, Kohler M, Gujer E, Zennegg M, Wenger D, Wichser A, Ulrich A, Gfeller U, Honegger P, Zeyer K, Emmenegger L, Petermann J.L, Czerwinski J, Mosimann T, Kasper M, Mayer A. (2008), 'Secondary effects of catalytic diesel particulate filters: conversion of PAHs versus formation of nitro-PAHs'. Environ Sci Technol., 42(10):3773-3779., https://doi.org/10.1021/es7026949

Heeb N.V, Schmid P, Kohler M, Gujer E, Zennegg M, Wenger D, Wichser A, Ulrich A, Gfeller U, Honegger P, Zeyer K, Emmenegger L, Petermann JL, Czerwinski J, Mosimann T, Kssssssasper M, Mayer A. (2010), 'Impact of low- and high-oxidation diesel particulate filters on genotoxic exhaust constituents'. Environ Sci Technol 44(3):1078-1084.,https://doi.org/10.1021/es9019222

Heitkamp M. A., Freeman J. P., Miller D. W., Cerniglia C. E. (1988).'Pyrene Degradation by a Mycobacterium dp: Identification of Ring Oxidation and Ring Fission Products'. Appl Environ Microbiol, 54, 2556-2565., https://doi.org/10.1128/aem.54.10.2556-2565.1988

Hinrichsen, D. (1997) 'Coastal Waters of the World: Trends, Threats and Strategies'; Island Press: Washington DC, 1997; p 7

Hofrichter M. (2002). 'Review: lignin conversion by manganese peroxidase (MnP)'. Enz. Microbiol. Technol, 30, 454-466., https://doi.org/10.1016/S0141$\underline{0229(01) 00528-2}$

Holmberg B. and Ahlborg U. (1983) 'Consensus report: mutagenicity and carcinogenicity of car exhausts and coal combustion emissions', Envir. Hlth Perspec. 47, 1-30.https://doi.org/10.2307/3429495

Huling S. G., Pivetz B. E. (2006). 'In-situ chemical oxidation'.EPA/ $600^{\text {th }} / R$ 06/072.Cincinnati, OH: United States Environmental Protection Agency.

Hussain, K., Rahman, M., Prakash, A., \& Hoque, R. R. (2015). 'Street dust bound PAHs, carbon and heavy metals in Guwahati city - Seasonality, toxicity and sources'. Sustainable Cities and Society. 19, 17-25. 
Hu S, Herner JD, Robertson W, Kobayashi R, Chang MCO, Huang SM, Zielinska B, Kado N, Collins JF, Rieger P, Huai T, Ayala A. (2013), 'Emissions of polycyclic aromatic hydrocarbons (PAHs) and nitro-PAHs from heavy-duty diesel vehicles with DPF and SCR'. J Air Waste Manage Assoc 63(8):984-996., https://doi.org/10.1080/10962247.2013.795202

IARC (2014) 'Carcinogenicity of diesel-engine and gasoline-engine exhausts and some nitroarenes'. In: IARC monographs on the evaluation of carcinogenic risks to humans, vol 105. International Agency for Research on Cancer, Lyon, p. 714.

Johnsen, A. R., and Karlson, U. (2007). 'Diffuse PAH contamination of surface soils: environmental occurrence, bioavailability, and microbial degradation'. Appl. Microbiol. Biotechnol. 76, 533-543. https://doi.org/10.1007/s00253-007-1045-2

Juhasz A. L. (2000). 'Microbial degradation and detoxification of high molecular weight polycyclic aromatic hydrocarbons by Stenotrophomonas maltophilia strain VUN 10,003'.Lett. Appl. Microbial, 30, 396-401., https://doi.org/10.1046/j.1472765x.2000.00733

Kameda, T. (2011). 'Atmospheric Chemistry of Polycyclic Aromatic Hydrocarbons and Related Compounds'. J. health Sci. 57(6), 504511.https://doi.org/10.1248/jhs.57.504

Kanaly R. A., Harayama S. (2000). 'Biodegradation of high-molecular-weight polycyclic aromatic hydrocarbons by bacteria'. J. Bacteriol, 182, 2059-2067., https://doi.org/10.1128/JB.182.8.2059-2067.2000

Kazuichi Hayakawa(Ed). 'Polycyclic Aromatic Hydrocarbons. Environmental behaviour and toxicity in East Asia., (Emission of Polycyclic Aromatic Hydrocarbons and Nitrated Polycyclic Aromatic Hydrocarbons from diesel engine and vehicles), $2018\left(1^{\text {st }}\right)$ Ed, Springer

Ke L., Luo L., Wang P., Luan T., Tam N. F. Y. (2010). 'Effects of metals on biosorption and biodegradation of mixed polycyclic aromatic hydrocarbons by a fresh water green alga Selenastrum capricornutum'. Bioresour. Technol, 101, 6950-6961., https://doi.org/10.1016/j.biortech.2010.04.011

Keller, C. D., and Bidleman, T. F. (1984). 'Collection of airborne polycyclic aromatic hydrocarbons and other organics with a glass fiber filter-polyurethane foam system'. Atmos. Environ. 18(4),837-845. https://doi.org/10.1016/0004-6981(84)90269-5

Kelley I., Freeman J. P., Cerniglia C. E. (1991). 'Identification of Metabolites from the Degradation of Naphthalene by a Mycobacterium sp'. Biodegradation, 1, 283-290., https://doi.org/10.1007/BF00119765

Keum Y. S., Seo J. S., Li Q. X., Kim J. H. (2008). 'Comparative metabolomic analysis of Sinorhizobium sp. C4 during the degradation of phenanthrene'. Appl. Microbiol. Biotechnol, 80, 863-872., https://doi.org/10.1007/s00253-008-1581-4 
Khalek I.A, Blanks M.G, Merritt P.M, Zielinska B. (2015).,'Regulated and unregulated emissions from modern 2010 emissions-compliant heavy-duty onhighway diesel engines'. J Air Waste Manage Assoc., 65(8):987-1001., https://doi.org/10.1080/10962247.2015.1051606

Khemili - Talbi S., Kebbouche - Gana S., Akmoussi-Toumi S., Angar Y., Gana M. L. (2015). 'Isolation of an extremely halophilic archaeon Natrialba sp. C21able to degrade aromatic compounds and to produce stable biosurfactant at high salinity'. Extremophiles, 19, 1109-1120., https://doi.org/10.1007/s00792-015-0783-9

Kohei Ito, Yuki Nanjo, Akinori Zukeran, Takashi Inui, (2017),, "Removal PAHs emitted from diesel engine using an electrostatic precipitator", Proceeding of 87 th JIME Conference, pp. 83 - 84, ISSN 1346-1435, 2017 (in Japanese).

Korfmacher W. A., Wehry E. L., Mamantov G., Natusch D. F. S. (1980). 'Resistance to photochemical decomposition of polycyclic aromatic hydrocarbons vapor-adsorbed on coal fly ash'. Environ. Sci. Technol, 14, 1094-1099., https://doi.org/10.1021/es60169a019

Kuo, C. Y., Chien, P.S., Kuo, W.C., Wei, C.T., and Rau, J. Y. (2012). 'Comparison of polycyclic aromatic hydrocarbon emissions on gasoline- and diesel-dominated routes'. Environ Monit Assess. 185(7), 5749-5761. https://doi.org/10.1007/s10661$\underline{012-2981-6}$

Kumar V, Kothiyal NC (2011). Distribution behavior of polycyclic aromatic hydrocarbons in roadside soil at traffic intercepts within developing cities; Int $J$ of Environ Sci and Tech.8(1), 63-72.

Kumar V, Kothiyal NC (2011a). Distribution Pattern and Contamination Levels of some Aromatic Hydrocarbons along Roadside Soil at Major Traffic Intercepts during Autumn in Jalandhar, India; Asian J of Chem23(3), 1363-1368.

Kumar V, Kothiyal NC (2012). Distribution behavior and carcinogenic level of some polycyclic aromatic hydrocarbons in roadside soil at major traffic intercepts within a developing city of India; Environ Monit and Assess. 184, 6239-6252.

Kumar V, Kothiyal NC and Saruchi, (2014). Studies on Carcinogenic PAHs Emission Generated by Vehicles and its Correlation to Fuel and Engine Types, Polish J of Chem Tech. 16(1), 48-58.

Kveseth, K., Sortland, B., and Bokn, T. (1982). 'Polycyclic aromatic hydrocarbons in sewage, mussels and tap water' Chemosphere. 11(7), 623-639. https://doi.org/10.1016/0045-6535\%2882\%2990173-4

Lamichhane S., Krishna K. C. B., Sarukkalige R. (2016). 'Polycyclic aromatic hydrocarbons (PAHs) removal by sorption: A review., Chemosphere' 148, 336-353., https://doi.org/10.1016/j.chemosphere.2020.127529 
Lannero, E., Wickman, M., Hage, M. V., Bergstrom, A., Pershagen, G., and Nordvall, L. (2008). 'Exposure to environmental tobacco smoke and sensitisation in children'. Thorax. 63(2),172-176. https://doi.org/10.1136/thx.2007.079053

Larsen, R. K., and Baker, J. E. (2003). 'Source apportionment of polycyclic aromatic hydrocarbons in the urban atmosphere: A comparison of three methods'. Environ. Sci. Technol. 37(9),1873-1881. https://doi.org/10.1021/es0206184

Lawal, A. T.(2017). 'Polycyclic aromatic hydrocarbons. A review'. Cogent Environ. Sci. 3(1) https://doi.org/10.1080/23311843.2017.1339841

Lee, B.-K., and Vu, V. T. (2010). 'Sources, distribution and toxicity of polyaromatic hydrocarbons (PAHs) in particulate matter,' in Air Pollution, (London: Intech Open), 99-122.https://doi.org/10.5772/10045

Legrini O., Oliveros E., Braun A. M. (1993). 'Photochemical processes for water treatment'. Chemical Reviews, 93, 671-698., https://doi.org/10.1021/cr00018a003

Li J. L., Chen B. H. (2009). 'Effects of non-ionic surfactants on biodegradation of phenanthrene by marine bacteria of Neptun omnasnaphthovorans'. J Hazard Mater., 162, 66-73., https://doi.org/10.1016/j.jhazmat.2008.05.019

Li J., Zhao L., Quin L., Tian X., Wang A., Zhou Y., Chen Y. (2016). 'Removal of refractory organics in nanofiltration concentrates of municipal solid waste leachate treatment plants by combined Fenton oxidative-coagulation with photo-Fenton processes'. Chemosphere, 146, 442-449., https://doi.org/10.1016/j.chemosphere.2015.12.069

Li X., Lin X., Zhang J., Wu Y., Yin R., Feng Y. (2010). 'Degradation of Polycyclic aromatic hydrocarbons by crude extracts from spent mushroom substrate and it's possible mechanisms'. Curr. Microbiol. 60, 336-342., https://doi.org/10.1007/s00284$\underline{009-9546-0}$

Lian L., Yao B., Hou S., Fang J., Yan S., Song W. (2017). 'Kinetic study of hydroxyl and sulphate radical-mediated oxidation of pharmaceuticals in wastewater effluents'. Environ Sci. Technol, 51, 2954-2962., https://doi.org/10.1021/acs.est.6b05536

Luning P. D., Pritchard P. H. (2002). 'Solubilization of polycyclic aromatic hydrocarbons mixtures in micellular non-ionic surfactant solution'. Water Res, 36, 3463-3472., https://doi.org/10.1016/s0043-1354(02)00070-2

Luo, Z.-H., Wei, C.-L., He, N.-N., Sun, Z.-G., Li, H.-X., and Chen, D. (2015). 'Correlation between the photocatalytic degradability of PAHs over $\mathrm{Pt} / \mathrm{TiO} 2-\mathrm{SiO} 2$ in water and their quantitative molecular structure'. Journal of Nanomaterials, 284834.,1-11., https://doi.org/10.1155/2015/284834 
M. Naushad (2014). Surfactant assisted nano-composite cation exchanger: Development, characterization and applications for the removal of toxic $\mathrm{Pb}^{2+}$ from aqueous medium, Chem. Eng. J. 235,100-108.

M. Naushad, A. Mittal, M. Rathore, V. Gupta (2015). Ion-exchange kinetic studies for $\mathrm{Cd}(\mathrm{II}), \mathrm{Co}(\mathrm{II}), \mathrm{Cu}(\mathrm{II})$, and $\mathrm{Pb}(\mathrm{II})$ metal ions over a composite cation exchanger, Desalin. Water Treat. 54, 2883-2890.

M. Naushad, Z.A. AL Othman, M.R. Awual, M.M. Alam, G.E. Eldesoky (2015a). Adsorption kinetics, isotherms, and thermodynamic studies for the adsorption of $\mathrm{Pb} 2+$ and $\mathrm{Hg} 2+$ metal ions from aqueous medium using $\mathrm{Ti}(\mathrm{IV})$ iodovanadate cation exchanger, Ionics (Kiel). 21, 2237-2245.

M. Naushad, G. Sharma, Z.A. Alothman (2019). Photodegradation of toxic dye using Gum Arabic-crosslinked-poly(acrylamide)/ $\mathrm{Ni}(\mathrm{OH}) 2 / \mathrm{FeOOH}$ nanocomposites hydrogel, J. Clean. Prod. 241, 118263.

Ma J., Xiao R., Li J., Yu J., Zhang Y., Chen L. (2010). 'Determination of 16 polycyclic aromatic hydrocarbons in environmental water samples by solid-phase extraction using multi-walled carbon nanotubes as adsorbent coupled with gas chromatography - mass spectrometry'. J. Chromatogr. A 1217,5462-5469., https://doi.org/10.1016/j.chroma.2010.06.060.

Mahaffey WR., Gibson D.T., Cerniglia C.E. (1998). 'Bacterial Oxidation of Chemical Carcinogens: Formation of Polycyclic Aromatic Acids from Benz(a) Anthracene'. Appl Environ Microbiol, 54, 2415-2423., https://doi.org/10.1128/aem.54.10.2415$\underline{2423.1988}$

Malloy, T. A., Goldfarb, T. D., Surico, M. T. J. (1993). 'PCDDS, PCDFs, PCBs, chlorophenols (CPs) and chlorobenzenes (CBzs) in samples from various types of composting facilities in the United States'. Chemosphere. 27(1-3),325-334. https://doi.org/10.1016/0045-6535(93)90309-S

Manoli, E., and C Samara, C. (1999). 'Polycyclic aromatic hydrocarbons in natural waters: sources, occurrence and analysis'. TrAC-Trend Anal Chem.,18(6),417-428. https://doi.org/10.1016/S0165-9936(99)00111-9

Marques M., Mari M., Audi-Miro C., Sierra J., Soler A., Nadal M., Domingo J. L. (2016). 'Photodegradation of polycyclic aromatic hydrocarbons in soils under a climate change base scenario'. Chemosphere, 148, 495-503., https://doi.org/10.1016/j.chemosphere.2020.127529

May, W. E., and Wise, S. A. (1984). 'Liquid chromatographic determination of polycyclic aromatic hydrocarbons in air particulate extracts'. Anal. Chem. 56(2),225232. https://doi.org/10.1021/ac00266a024 
McCutcheon S. C., Schnoor J. L. (2003). 'Phytoremediation: transformation and control of contaminants'. Wiley-Inter Science, Hoboken, P 987

MECA (2007)., 'Emission control technologies for diesel-powered vehicles'., Manufacturers of Emission Controls Association, Washington, DC

Menzie, C. A., Potocki, B. B., and Santodonato, J. (1992). 'Exposure to carcinogenic PAHs in the environment'. Environ. Sci. Technol. 26(7), 1278-1284. https://doi.org/10.1021/es00031a002

Meyer, S., Cartellieri, S., and Steinhart, H. (1999). 'Simultaneous determination of PAHs, hetero PAHs ( $\mathrm{N}, \mathrm{S}, \mathrm{O})$, and their degradation products in creosote contaminated soils. Method development, validation, and application to hazardous waste sites'. Anal. Chem. 71(18),4023-4029. https://doi.org/10.1021/ac990136j

Miller, J. D., Facanha C., (2014). 'Synthesis of Vehicle and Fuel Policy Developments'. ICCT The state of clean transport policy.

Miura, K., Shimada, K., Sugiyama, T., Sato, K., Takami, A., Chan, C. K., Kim, I. S., Kim, Y. P., Lin, N. H., and Hatakeyama, S. (2019). 'Seasonal and annual changes in PAH concentrations in a remote site in the Pacific Ocean'. Sci Rep 9, 12591. https://doi.org/10.1038/s41598-019-47409-9

Mojiri, A., Zhou, J. L., Ohashi, A., Ozaki, N., and Kindaichi, T. (2019). 'Comprehensive review of polycyclic aromatic hydrocarbons in water sources, their effects and treatments'. Sci. Total Environ. 2019:133971. https://doi.org/10.1016/j.scitotenv.2019.133971

Mojiri, A., Zhou, J. L., Ohashi, A., Ozaki, N., and Kindaichi, T. (2019). Comprehensive review of polycyclic aromatic hydrocarbons in water sources, their effects and treatments. Sci. Total Environ. 2019:133971. https://doi.org/10.1016/j.scitotenv.2019.133971

Monna L., Omori T., Kodama T. (1993). 'Microbial Degradation of Dibenzofuran, Fluorene and Dibenzo-P-Dioxin by Staphylococcus auricularis DBF63'. Appl Environ Microbiol, 59, 285-289., https://doi.org/10.1128/aem.59.1.285-289.1993

Muller J. G., Chapman PJ., Blattmann B. O., Pritchard P. H. (1990). 'Isolation and Characterization of a Fluoranthene-Utilizing Strain of Pseudomonas paucimobilis'. Appl Environ Microbiol, 56, 1079-1086., https://doi.org/10.1128/aem.56.4.1079$\underline{1086.1990}$

Ndimele P. E., Oni A. J., Jibuike C. C. (2010). 'Comparative toxicity of crude oil-plus dispersant to Tilapia guineensis'. Res J Environ Toxicol, 4(1): 13-22., https://doi.org/10.3923/rjet.2010.13.22 
Nesatyy V. J., Sutter M. J. (2007). 'Proteomics for the analysis of environmental stress responses in organisms'. Environ Sci. Technol, 41, 6891-6900., https://doi,org/10.1016/S0065-2164(02)51007-8

Nguyen V. H., Thi L. A. P., Le Q. V., Singh P., Raizada P., Kajitvichyanukul P. (2020). 'Tailored photocatalysts and revealed reaction pathways for photodegradation of polycyclic aromatic hydrocarbons (PAHs) in water, soil and other sources'. Chemosphere, 260; 127529., https://doi.org/10.1016/j.chemosphere.2020.127529

Nielsen T. (1996). 'Traffic Contribution of Polycyclic aromatic hydrocarbons in the centre of large city'. Atmos Environ; 30 3481-3490., https://doi.org/10.1016/1352$\underline{\text { 2310(96)00096-9 }}$

Ohura, T., Amagai, T., Fusaya, M., and Matsushita, H. (2004). 'Polycyclic Aromatic Hydrocarbons in indoor and outdoor environments and factors affecting their concentrations'. Environ. Sci. Technol, 77-83. https://doi.org/10.1021/es030512o

Ojha N., Mandal S. K., Das N. (2019). 'Enhanced degradation of indeno (1, 2,3-cd) pyrene using Candida tropicalis NN4 in presence of iron nanoparticles and produced biosurfactant: a statistical approach'. 3 Biotech 9, (3),86., https://doi.org/10.1007/s13205-019-1623-x

Okoro H. K., Asaju R. O., Ogunkunle C. O., Basheeru K. A. (2020). 'Sources, Fate and Degradation of Polycyclic Aromatic Hydrocarbons in the Environment'. Niger. J. Pharm. Sci., 9(2): 67-75., https://nijophasr.net/index.php/nijophasr/article/view/334

Oleszczuk P., Hale S. E., Lehmann J., Cornelissen G. (2012). 'Activated carbon and biochar amendments decrease pore-water concentrations of polycyclic aromatic hydrocarbons (PAHs) in sewage sludge'. BioresourTechnol, 111, 84-91., https://doi.org/10.1016/j.biortech.2012.02.030

Omar, N. Y. M. J., Abas, M. R. B., Ketuly, K. A., and Tahir, N. M. (2002). 'Concentration of PAHs in atmospheric particles (PM10) and roadside soil particles collected in Kuala Lumpur, Malaysia'. Atmos. Environ. 36(2),247-254. https://doi.org/10.1016/S1352-2310(01)00425-3

Pace N.R., Stahl D. A., Lane D. J., Olsen G. J. (1986). 'The analysis of natural microbial populations by ribosomal RNA sequences'. Adv. Microbial. Ecol, 9, 1-55., https://doi.org/10.1007/978-1-4757-0611-6_1

Patel A. B., Shaikh S., Jain K. R., Desai C., Madamwar D. (2020). 'Polycyclic Aromatic Hydrocarbons: Sources, Toxicity and Remediation Approaches'.FRONT MICROBIOL., 11:562813., https://doi.org/10.3389/fmicb.2020.562813

Patel, A. B., Shaikh, S., Jain, K. R., Desai, C., and Madamwar, D. (2020). 'Polycyclic Aromatic Hydrocarbons: Sources, Toxicity, and Remediation Approaches'. Front. Microbiol. 11, 2675. https://doi.org/10.3389/fmicb.2020.562813 
Perera F., Wang S., Vishnevetsky J., Zhang B., Cole K. J., Tang D. (2011). 'Polycyclic Aromatic Hydrocarbons-Aromatic DNA Adducts in Cord Blood and Behavior Scores in New York City Children'. Environ Health Perspect, 119, 11761181., https://doi.org/10.1289/ehp.1002705

Petty, J. D., Huckins, J. N., and Zajicek, J. L. (1993). 'Application of semipermeablemembrane devices (SPMDs) as passive air samplers'. Chemosphere. 27(9), 16091624. https://doi.org/10.1016/0045-6535(93)90143-S

Polycyclic organic matter (POM). Washington, DC: US Environmental Protection Agency; 2007.

Polynuclear aromatic hydrocarbons (PAH). In: Air quality guidelines for Europe. Copenhagen, World Health Organization Regional Office for Europe, 1987, pp. 105117. https://apps.who.int/iris/handle/10665/107364

Quinn L., Pieters R., Nieuwoudt C., Borgen A. R., Kylin H., Bouwman H. (2009). 'Distribution profiles of selected organic pollutants in solid and sediments of industrial, residential and agricultural areas of South Africa'. Journal of Environ. Monit., 11, 1647-1657., https://doi.org/10.1039/B905585A

Ravindra, K., Sokhi, R., and Van Grieken, R. (2008). 'Atmospheric polycyclic aromatic hydrocarbons: source attribution, emission factors and regulation'. Atmos. Environ. 42, 2895-2921. https://doi.org/10.1016/j.atmosenv.2007.12.010

Reisen F., Arey J. (2002). 'Reactions of hydroxyl radicals and ozone with acenaphthene and acenaphthylene'. Environ Sci Technol, 36, 4302-4311., https://doi.org/10.1021/es025761b

S.W. Moore and S. Ramamoorthy, in R.S. Desanto (Series Editor), Organic Chemicals in Natural Waters. Applied Monitoring and Impact Assessment. Springer Verlag, New York, 1984.

S. Pandey, E. Fosso-Kankeu, J. Redelinghuys, J. Kim, M. Kang (2021), Implication of biofilms in the sustainability of acid mine drainage and metal dispersion near coal tailings, Science of The Total Environment, 788, 147851, https://doi.org/10.1016/j.scitotenv.2021.147851

S. Pandey, J Y Do, J Kim, M Kang (2020), Fast and highly efficient catalytic degradation of dyes using $\kappa$-carrageenan stabilized silver nanoparticles nanocatalyst, Carbohydrate Polymers, 230,115597,https://doi.org/10.1016/j.carbpol.2019.115597.

S. Pandey, J. Y. Do, J. Kim, M. Kang (2020a), Fast and highly efficient removal of dye from aqueous solution using natural locust bean gum-based hydrogels as adsorbent, International Journal of Biological Macromolecules,143,60-75, https://doi.org/10.1016/j.ijbiomac.2019.12.002. 
Sakshi Singh S. K., Haritash A. K. (2019). 'Polycyclic aromatic hydrocarbons:soil pollution and remediation'.Int. J. Environ. Sci. Technol, 16, 6489-6512., https://doi.org/10.1007/s13762-019-02414-3

Samanta S. K. (2002). 'Singh O. V., Jain R. K., Polycyclic aromatic hydrocarbons: environmental pollution and bioremediation'. Trends Biotechnol., 20 243-8., https://doi.org/10.1016/s0167-7799(02)01943-1

Saiyasitpanich Phirun, Keener Tim C, Lu Mingming, Liang Fuyan, Khang Soon-Jai, (2008)., "Control of Diesel Gaseous and Particulate Emissions with a Tube-Type Wet Electrostatic Precipitator", J. Air \& Waste Manag. Assoc., Vol. 58, No. 10, pp. 13111317, [15]., https://doi.org/10.3155/1047-3289.58.10.1311

Schauer JJ, Kleeman MJ, Cass GR, Simoneit BRT., (1999)., 'Measurement of emissions from air pollution sources. 2. C-1 through C-30 organic compounds from medium duty diesel trucks'. Environ Sci Technol 33(10):1578-1587., https://doi.org/10.1021/es980081n

Schwarzenbach R. P., Gschwend P. M., Imboden D. M, Environmental organic chemistry, John Wiley and Sons, Inc, (1993).

Sharp C.A, Howell S.A, Jobe J. (2000), 'The effect of biodiesel fuels on transient emissions from modern diesel engines, Part II Unregulated emissions and chemical characterization'. SAE International. Paper \# 2000-01-1968., https://doi.org/10.4271/2000-01-1968

Shiraishi, H., Pilkington, N. H., Otsuki, A., and Fuwa, K. (1985). 'Occurrence of chlorinated polynuclear aromatic hydrocarbons in tap water'. Environ Sci Technol. 19(7), 585-590. https://doi.org/10.1021/es00137a001

Silva I. S., Grossman M., Durrant. L. R. (2009). 'Degradation of polycyclic aromatic hydrocarbons (2-7 rings) under microaerobic and very-low-oxygen conditions by soil fungi'. Int. Biodeterior. Biodegradation, 2, 224-229., https://doi.org/10.1016/j.ibiod.2008.09.008

Smol M., Wlodarczyk- Makula M. (2016). 'The Effectiveness in the Removal of PAHs from Aqueous Solutions in Physical and Chemical Processes: A Review'. Polycycl. Aromat, 6638, 1-22., https://doi.org/10.1080/10406638.2015.1105828

Soleimani M.(2012).'Bioremediation: An environmental friendly solution for oil contaminated soils'. J BioremedBiodegrad, 3(4)., https://doi.org/10.4172/2155$\underline{6199.1000 \mathrm{e} 109}$

Speizer F. E. (1986) Overview of the risk of respiratory cancer from airborne contaminants. Envir. Hlth Perspec. 70, 9-15. https://doi.org/10.1289/ehp.86709 
Spongberg, A. L., and Witter, J. D. (2008). 'Pharmaceutical compounds in the wastewater process stream in Northwest Ohio'. Sci. Total Environ. 397(1-3), 148-157. https://doi.org/10.1016/j.scitotenv.2008.02.042

Srogi K. (2007). 'Monitoring of environmental exposure to polycyclic aromatic hydrocarbons: a review'. Environ Chem Lett 5, 169-195. https://doi.org/10.1007/s10311-007-0095-0

Srogi K. Monitoring of environmental exposure to polycyclic aromatic hydrocarbons: a review. Environmental Chemistry Letters. 2007; 5:169-195. [PMC free article: PMC5614912] [PubMed: 29033701]

Suman, S., Sinha, A., and Tarafdar, A., (2016). 'Polycyclic aromatic hydrocarbons (PAHs) concentration levels, pattern, source identification and soil toxicity assessment in urban traffic soil of Dhanbad, India'. Sci. Total Environ. 545546,353-360. https://doi.org/10.1016/j.scitotenv.2015.12.061

Sun K., Liu J., Gao Y., Jin L., Gu Y., Wang W. (2014). 'Isolation, plant colonization potential and phenanthrene degradation performance of the endophytic bacterium Ph6-gfp'.Sci Rep, 4, 5462., https://doi.org/10.1038/srep05462

Sun T. R., Cang L., Wang Q. K., Zhou D. M., Cheng J. M., Xu H. (2010). 'Roles of abiotic losses, microbes, plant roots, and root exudates on phytoremediation of PAHS in a barren soil'. J Hazard Mater, 176, 919-925., https://doi.org/10.1016/j.jhazmat.2009.11.124

Tang, L., Tang, X., Zhu, Y., Zheng, M., and Miao, Q. (2005). 'Contamination of polycyclic aromatic hydrocarbons (PAHs) in urban soils in Beijing, China'. Environ. Int. 31(6),822-828. https://doi.org/10.1016/j.envint.2005.05.031

Tang, N., Hattori, T., Taga, R., Igarashi, K., Yang, X. Y,. Tamura, K., Kakimoto, H., Mishukov, V. F., Toriba, A., Kizu, R., and Hayakawa, K. (2005). 'Polycyclic aromatic hydrocarbons and nitropolycyclic aromatic hydrocarbons in urban air particulates and their relationship to emission sources in the Pan-Japan Sea countries'. Atmos. Environ. 39(32),5817-5826. https://doi.org/10.1016/j.atmosenv.2005.06.018

Tolosa, I., Bayona, J. M., and Albaiges, J. (1996). 'Aliphatic and polycyclic aromatic hydrocarbons and sulfur/oxygen derivatives in Northwestern Mediterranean sediments: Spatial and temporal variability, fluxes, and budgets' Environ. Sci. Technol.,30(8), 2495-2503. https://doi.org/10.1021/es950647x

Tortella G. R., Diez M. C., Duran N. (2005). 'Fungal diversity and use in decomposition of environmental pollutants'. Crit. Rev. Microbial, 31, 197-212., https://doi.org/10.1080/10408410500304066

Ukiwe L. N., Egereonu U. U., Njoku P. C., Nwoko C. I. A., Allinor J. I. (2013). 'Polycyclic Aromatic Hydrocarbons Degradation Techniques: A Review'. International Journal of Chemistry, (5)., https://doi.org/10.1016/j.chemosphere.2020.127529 
Unwin, J., Cocker, J., Scobbie, E., and Chambers, H. (2006). 'An assessment of occupational exposure to polycyclic aromatic hydrocarbons in the UK'. Ann Occup Hyg. 50(4), 395-403. https://doi.org/10.1093/annhyg/mel010

Verma, R., Patel, K. S., and Verma, S. K. (2015). 'Indoor polycyclic aromatic hydrocarbon concentration in Central India'. Polycycl Aromat Compd. 36(2), 1-17. http://dx.doi.org/10.1080/10406638.2014.957407

Vinas M., Sabate J., Espuny M. J., Solanas A. M. (2005). 'Bacterial community dynamics and polycyclic aromatic hydrocarbon degradation during bioremediation of heavily creosote-contaminated soil'. Appl Environ Microbiol, 71, 7008-18., https://doi.org/10.1128/AEM.71.11.7008-7018.2005

Walter U., Beyer M., Klein J., Rehm H.J. (1991). 'Degradation of Pyrene by Rhodococcus sp. UW'. Appl Microbiol Biotechnol, 34, 671-676., https://doi.org/10.1007/BF00167921

Wang H., Kim B., Wunder S. L. (2015). 'Nanoparticles-Supported lipid bilayers as an in situ remediation strategy for hydrophobic organic contaminants in soils'. Environ. Sci. Technol., 49, 529-536., https://doi.org/10.1021/es504832n

Wang J., Wang C., Huang Q., Ding F., He X. (2015). 'Adsorption of PAHs on the sediments from the yellow river Delta as a function of particle size and Salinity'. oil Sediments Contam. Int. J, 24, 103-115., https://doi.org/10.1080/15320383.2014.920292

Wang, Y., Tian, Z., Zhu, H., Cheng, Z., Kang, M., Luo, C., Li, J., and Zhang, G. (2012). 'Polycyclic aromatic hydrocarbons (PAHs) in soils and vegetation near an e-waste recycling site in South China: concentration, distribution, source, and risk $\begin{array}{llll}\text { assessment'. } & \text { Sci } & \text { Total } & \text { Environ.439, }\end{array}$ https://doi.org/10.1016/j.scitotenv.2012.08.018

Wang, Z., Ren, P., Sun, Y., Ma, X., Liu, X., Na, G., and Yao, Z. (2013). 'Gas/particle partitioning of polycyclic aromatic hydrocarbons in coastal atmosphere of the north Yellow Sea, China'. Environ Sci Pollut Res 20, 5753-5763. https://doi.org/10.1007/s11356-013-1588-y

Wang, Z., Yang, C., Parrott, J. L., Frank, R.A., Yang, Z., Brown, C. E., Hollebone, B. P., Landriault, M., Fieldhouse, B., Liu, Y., Zhang, G., and Hewitt, L. M. (2014). 'Forensic source differentiation of petrogenic, pyrogenic, and biogenic hydrocarbons in Canadian oil sands environmental samples'. J. Hazard. Mater., 271 166-177. https://doi.org/10.1016/j.jhazmat.2014.02.021

Wania, F., Haugen, J. E., Lei, Y. D., and Mackay, D. (1998). 'Temperature dependence of atmospheric concentrations of semi volatile organic compounds'. Environ. Sci. Technol. 32(8),1013-1021. https://doi.org/10.1021/es970856c 
Weissenfels W. D., Beyer M., Klein J. (1990). 'Degradation of Phenanthrene, Fluorene and Fluoranthene by Pure bacterial Cultures 1'. Appl Microbiol Biotechnol, 32, 479-484., https://doi.org/10.1007/BF00903787

Weissenfels W. D., Beyer M., Klein J., Rehm H. J. (1991). 'Microbial Metabolism of Fluoranthene: Isolation and Identification of Ring Fission Products'. Appl Microbiol Biotechnol, 34, 528-535., https://doi,org/10.1007/BF00180583

Westerholm R. N., Alsberg T. E., Frommelin A. B., Strandell M. E., Rannug U., Winquist L., Grigoriadis V., Egeback K. E. (1988). 'Effect of fuel polycyclic aromatic hydrocarbon content on the emissions of polycyclic aromatic hydrocarbons and other mutagenic substances from a gasoline-fueled automobile'. Environ Sci Technol, 22(8),925-930., https://doi.org/10.1021/es00173a010

White, A. J., Bradshaw, P. T., Herring, A. H., Teitelbaum, S. L., Beyea, J., Stellman, S. D., Steck, S. E., Mordukhovich, I., Eng, S. M., Engel, L. S., Conway, K., Hatch, M., Neugut, A. I., Santella, R. M., and Gammon, M. D. (2016). 'Exposure to multiple sources of polycyclic aromatic hydrocarbons and breast cancer incidence'. Environ Int. 89-90, 185-192. https://dx.doi.org/10.1016\%2Fj.envint.2016.02.009

Wu M., Chen L., Tian Y., Ding Y., Dick W. A. (2013). 'Degradation of polycyclic aromatic hydrocarbons by microbial consortia enriched from three soils using two different culture media'. Environ Pollut, 178, 152-158., https://doi.org/10.1016/j.envpol.2013.03.004

Yuki Nanjo, Akinori Zukeran, Takashi Inui, (2016)., "Analysis and plasma treatment of Polycyclic Aromatic Hydrocarbons in diesel exhaust gas", Proceeding of 86th JIME Conference, pp. 65 - 66, ISSN 1346-1435, 2016 (in Japanese)

Zhang L., Li P., Gong Z., Li X. (2008). 'Photocatalysis degradation of polycyclic aromatic hydrocarbons on soil surfaces using TiO2 under UV light'. Journal of Hazardous Materials, 158, 478-484., https://doi.org/10.1016/j.jhazmat.2008.01.119

Zhang M. H., Dong H., Zhao L., Wang D-X., Meng D. (2019). 'A review on Fenton process for organic wastewater treatment based on optimization perspective'. Sci Total Environ, 670, 101-121., https://doi.org/10.1016/j.scitotenv.2019.03.180

Zhang, Y., Tao, S., (2009). 'Global atmospheric emission inventory of polycyclic aromatic hydrocarbons (PAHs) for 2004'. Atmos. Environ., 43(4), 812-819. https://doi.org/10.1016/j.atmosenv.2008.10.050

Zoller, U. (1993). 'Groundwater Contamination by Detergents and Polycyclic Aromatic Hydrocarbons - A Global Problem of Organic Contaminants: Is the Solution Locally Specific?'. Water Sci Technol. $27 \quad$ (7-8), 187194.https://doi.org/10.2166/wst.1993.0551 